\title{
Assessment of well water pollution by sewage contaminants: A case study of Akure South, Ondo State, Nigeria
}

\section{Josiah Abolade Owoeye* and Joseph Onaolapo Akinneye}

Department of Biology. PMB 704. Federal University of Technology. Akure. Ondo State. Nigeria.*Email: owoeyeabolade@yahoo.com.

\begin{abstract}
This study investigated the extent of well water contamination in dry and rainy seasons through infiltration of coliform bacteria from sewage pits in their proximity in Akure. Total and Faecal coliform counts of twenty household wells were investigated between the months of March and July with respect to proximity of wells to sewage pits, orientation of wells to sewage pits, and other well characteristics. All wells studied were assessed to be vulnerable to contamination with observable differences in characteristics, physicochemical parameters, total coliform counts and faecal coliform counts. Asides $\mathrm{pH}$ which was higher in the dry season, all other parameters had lower values in the dry season. At an average distance of $17.6 \mathrm{~m}$ from the sewage pits, all well water sampled had greater coliform counts than the WHO recommended level for drinking water $(<1 \mathrm{cfu} / \mathrm{mL})$. Correlations between coliform counts of water samples and the distances of the wells to sewage pits was positive and not significant for both total and faecal coliform in dry season, while it was negative and significant for both total and faecal coliform in the rainy season. Topography, and distance between wells and sewage pits were prominent factors responsible for well water contamination. Amounts of coliforms found in wells were significantly affected by seasonal variation. It is thus suggested that wells be sited up-gradient and at safer distances away from sanitary systems in the ultimate bid to reduce groundwater pollution and the occurrence of water borne diseases.
\end{abstract}

\section{List of acronyms used}

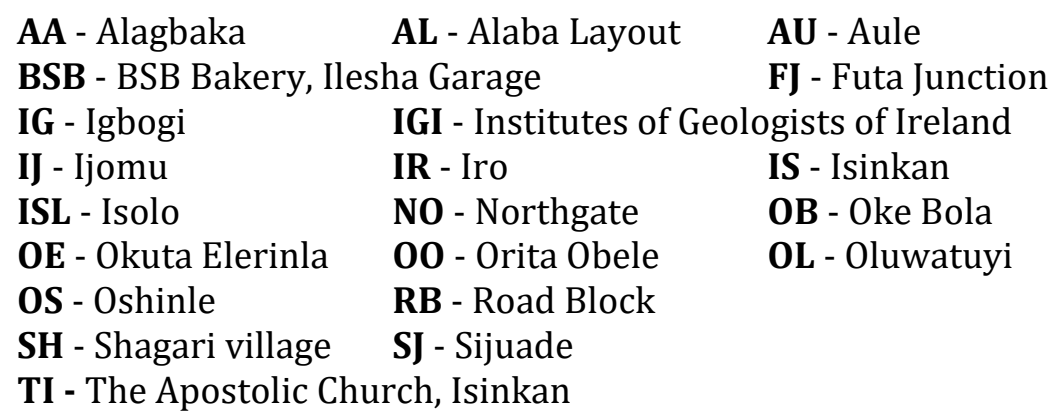

Keywords: Groundwater; Pollution; Sewage; Well water; Akure.
Received

April 23, 2018

Accepted

July 8, 2018

Released

August 31, 2018

Full Text Article

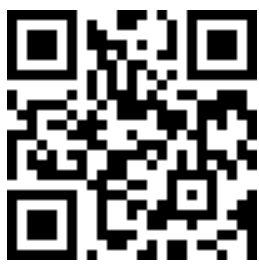

ORCID

(ㄱ) 0000-0002-1363-3259

Josiah Abolade

Owoeye

(D) 0000-0002-2672-1856

Joseph Onaolapo Akinneye 


\section{Introduction}

Safe drinking water is essential to humans and other life forms. Of all the water sources, groundwater serves as the most reliable and abundant source of water used for drinking and irrigation in many countries of the world. In the major cities of the world, water is provided to the public usually via a system of pumps and pipes. However, the prevailing state of unequal distribution of social amenities across major cities in most developing countries around the world had posed a lot of challenges to effectiveness and efficiency of infrastructures (Aladejana and Talabi, 2013). This situation can be attributed to both inaccessibility of piped water supply to people or its redundancy in many parts of Nigeria and several other African countries, especially in the smallsized communities and towns (Adelekan, 2010).

Water supply for domestic purposes in most Nigerian cities is plagued by various inadequacies and challenges (Adelekan, 2010; Orebiyi et al., 2010; Adetunji and Odetokun, 2011). These inadequacies and challenges which may include erratic power supply, insufficient water supply, burst and leaking pipes, sourcing for water, maintenance of pipes and remoteness of rural communities. These challenges are presumed to be as a result of enormous socio-economic rate of development, a growing industrial base, poor planning, insufficient funding, haphazard implementation of programs, lack of maintenance culture as well as technically deficient personnel (Sangodoyin, 1993). Given such a situation, communities have resorted to groundwater resources such as unprotected springs, shallow wells, boreholes and even rainfall as alternative sources of freshwater for domestic, industrial and agricultural purposes (Sridhar, 2000; Adelekan, 2010; WHO, 2006; Aladejana and Talabi, 2013). About sixty percent $(60 \%)$ of the Nigerian populace; both rural and some urban dwellers still source for domestic water, and sometimes drinking water from ponds, streams and shallow wells (WHO, 2006; Ekiye and Luo, 2010).

Overtime, certain problems have beset the use of groundwater around the world. Just as river waters have been over-used and polluted in many parts of the world, so too have aquifers (Morris et al., 2003). Taking a perfunctory look at the cities would reveal that majority of the water sources are prone to pollution due to urbanization, population increase and industrialisation (Sridhar, 2000; Longe and Balogun, 2010; Akinbile and Yusoff, 2011). Groundwater is especially vulnerable in areas where population density is high and human use of the land is intensive. Essentially, activities that lead to the release of chemicals or wastes into the environment, either deliberately or inadvertently, have the potential to pollute groundwater. Pollution from chemical and biological sources is evident in different urban centres (Sridhar, 2000; Akinbile and Yusoff, 2011).

Maintenance of groundwater quality has been a major problem in Nigerian cities. The rapid increase in population witnessed in Akure Metropolis since it became a state capital in 1976, has led to an increase in waste generation; the disposal of which has been poorly managed (Akinbile and Yusoff, 2011; Bayode et al., 2012). Many residents in the municipal have poor access to safe water and sanitation services while various households are predominated by pit and cesspool latrines. According to Oluwande (1985), about seventy-five percent $(75 \%)$ of the urban households in Nigeria make use of either pit or privy latrines. This situation is still obviously observable in Akure. The predominant use of pit latrines, privies and cesspool water closet toilet leading to the construction of underground septic tanks lead to 
microbial contamination of drinking water wells through underground water flow (Ushurhe and Origho, 2013).

Contamination of urban groundwater by seepages and leakages from sewage pits and channels is an increasing matter of public and regulatory concern (Eiswirth and Hotzl, 1997; Kumasi et al., 2011), as the migration of sludge-borne pathogens through soils into groundwater has been highlighted by environmentalists (USEPA, 1994). Proximity of septic tanks to wells and unhygienic usage of the wells are presumed to be the commonest causes of well water pollution (Adetunji and Odetokun, 2011). Disposal of solid or liquid wastes in pits, abandoned boreholes or even stream channels and landfills may also serve as sources of groundwater pollution (Onunkwo and Uzoije, 2011).

$\begin{array}{ccc}\text { Outbreaks } & \text { of } & \text { waterborne } \\ \text { diseases have been } & \text { significantly }\end{array}$
associated with the consumption of contaminated groundwater, mainly from private non-community wells (Moore et al, 1993; Kramer et al, 1996; Blackburn et al, 2004; FMWR, 2004). It is a matter of history that pollution of drinking water caused water borne diseases which wiped out entire population of cities (Birmingham et al., 1997). At present, polluted water has amplified the menace of water borne diseases and epidemics, which is still high in developing countries (Nollet, 2000). The proximity of sewage pits (such as pit latrines and septic tanks) and channels have been considered a major contributing factor to the contamination of such wells (Ogedengbe and Aina 1980).

As it is that most households should compulsorily have sewage pits and water wells in the same compound, concerns are thus growing over the sustainability of such individual water sources and there is a growing need for management strategies that recognize the complex linkages that exist between groundwater supplies and sewage disposal in septic tanks (Morris et al., 2003). Assessment of well water is therefore very crucial to safeguard public health and the environment (Lin et al., 2010), most especially in areas where sewage pits are in proximity to wells; as it is important to achieving potable water for daily consumption and sustainability of drinking water sources.

\section{State of water supply in Akure}

Municipal water supply in Akure; the capital city of Ondo State is the responsibility of the Ondo State Water Corporation (OSWC). The corporation collects water from various sources such as the rivers (Awara, Ose, Owena, and Osun) and rainfall, treats the water and then pumps to the populace through a system of pipes. In the alternative, water tankers are also used to supply water to areas where the pipe networks are not present. The corporation also sells treated water from their taps for a price determined by volume. As such, $10 \mathrm{~L}$ sell for N5 while $20 \mathrm{~L}$ sell for N10. To achieve an efficient supply of water, various Water Supply Schemes were set up in different locations of the state such as Akure, Ikare, Ondo, Okitipupa and Owo. They are however not adequate to cater for the populace in the present day (Table 1).

Efforts to mitigate the problems of water supply have not been adequate. A particular case in point was the 1998 tripartite agreement between the World Bank, Federal Government and Ondo State Government to rehabilitate, improve and expand public water supply network and its associated problems in Owo, Akure and Oke-Igbo. The project is yet to commence till present (Aribigbola and Omosulu, 2012). In the same vein, the rehabilitation and upgrade of the redundant major water supply schemes which had collapsed in some communities many years ago is yet to be completed. A recent report which stated that the Ondo State Government has constructed over 200 solar-powered industrial boreholes in various 
communities in the 18 Local Government Areas of the state, has done little or nothing in the government's bid to adequately provide potable water for the people (Aribigbola and Omosulu, 2012).

Table 1. Population of people receiving urban water supply in Akure.

\begin{tabular}{|c|c|c|c|c|c|c|}
\hline & \multirow{2}{*}{$\begin{array}{l}\text { Water supply } \\
\text { schemes }\end{array}$} & \multirow[t]{2}{*}{ Commissioned date } & \multicolumn{2}{|c|}{ Design capacity } & \multicolumn{2}{|c|}{ Present status } \\
\hline & & & $\mathrm{m}^{3} /$ day & $\begin{array}{c}\text { Target } \\
\text { Population }\end{array}$ & $\begin{array}{c}\text { Population } \\
\text { served }\end{array}$ & $\begin{array}{c}\text { Production level } \\
(\%)\end{array}$ \\
\hline 1 & Alagbaka & 1930 & 450 & 5,000 & - & - \\
\hline 2 & Okeigbo & 1961 & 2,275 & 30,000 & 21,132 & 95 \\
\hline 3 & Owena (Ondo) & 1965 & 23,424 & 787,000 & 206,131 & 90 \\
\hline 4 & Owena (IgbaraOke) & 1971 & 5,450 & 192,000 & 53,289 & 100 \\
\hline 5 & Ala River & 1980 & 1,360 & 15,000 & - & - \\
\hline 6 & Ukere/Oshinle & 1985 & 50 & 2,000 & 733 & 100 \\
\hline 7 & Odojomu B/H & 1986 & 165 & 2,000 & 4,033 & 100 \\
\hline 8 & School of Agric & 1988 & 675 & 2,000 & 8,910 & 90 \\
\hline 9 & Temidire $\mathrm{B} / \mathrm{H}$ & 1988 & 165 & 2,000 & 4,033 & 100 \\
\hline 10 & Babasale-Igbatoro & 2005 & 49.09 & 2,000 & 1,200 & 100 \\
\hline 11 & Familugba-Igbatoro & 2005 & 49.09 & 2,000 & 1,200 & 100 \\
\hline 12 & Igunsi-Igbatoro & 2005 & 49.09 & 2,000 & 1,200 & 100 \\
\hline 13 & Imafon-Igbatoro & 2005 & 49.09 & 2,000 & 1,200 & 100 \\
\hline 14 & Olobi-Igbatoro & 2005 & 49.09 & 2,000 & 1,200 & 100 \\
\hline
\end{tabular}

Source: OSWC (2014).

\section{Well water: The alternative water source}

The inadequacy of pipe borne water has made communities find alternative sources of water (Adetunji and Odetokun, 2011) such as ponds, streams, shallow wells, unprotected springs, boreholes and rainfall for domestic, industrial and agricultural uses (Adelekan, 2010; Aladejana and Talabi, 2013; Ekiye and Luo, 2010; Sridhar, 2000).

Wells particularly are the most readily available source of groundwater, explored to meet community water requirements or make up the short falls of the piped water supply (Adekunle, 2008). In effect, it is a global phenomenon that many people are dependent on private and public dug wells as their major source of water particularly in developing countries. Hence many homes have wells sited around the house (Abdusalam and Zubairu, 2013).

\section{Sewage treatment in Akure}

There are a number of treatment modes that are presently used in most developing countries for decentralised wastewater treatment or handling (Omenka, 2010). In Akure, the Septic tank-soak-away pit system is the most common type of on-site sewage treatment facility. The technologies employed use a number of simple, cost effective, low energy and easy to maintain methods such as anaerobic processes, ponds and earth based treatment options.

\section{Role of septic tank-soakaway pits in well water contamination}

Due to an increasing population size, an attendant increase in the development of well water in Akure is accompanied by an increase in the provision of on-site sanitation systems. This is based on the premise that there is no central Sewage treatment system in the city. As such, the provision of septic 
tanks and soakaway is considered a better choice of on-site sanitation facilities for excreta disposal (Olabisi et al., 2008); a situation which is also observable in other communities where groundwater is used for domestic purposes (Odai and Dugbantey, 2003).

There is a growing concern that the use of onsite sanitation facilities may result in groundwater contamination (Carrol et al., 2006) and subsequent diseases outbreak and transmission (Olabisi et al., 2008). Septic tanks produce liquid effluent which must be disposed of by infiltrating into the ground. The liquid effluent contains large numbers of bacteria which are dangerous. Since it is important that the effluents are only disposed of by infiltration and septic tanks are typically built where the soil is permeable and the liquid effluent they produce will infiltrate the soil, there is a high risk of groundwater contamination from soakaways, particularly where water table is very high.

Presently in Nigeria, most septic tanks are connected to soil water infiltration system for individual buildings. The design standards are not followed in most Nigerian cities, whereby the quality of effluent from the septic tank which should determine the design of the soakaway device is not considered in the construction (Burubai et al., 2007). Adetunji and Odetokun (2011) highlighted proximity of septic tanks to wells as the commonest cause of well water pollution. It has been estimated that the total volume of waste disposed-off via septic tanks is approximately 800 million gallon per year, virtually all of which is disposed in the subsurface (USEPA, 1977). This makes septic tanks the leading contributor to the total volume of waste discharged directly to ground water.

One gram of faecal material can contain 10 million viruses, 1 million bacteria, 1 million cysts, and a hundred eggs of worms (Quenum, 2003). Unfortunately millions of persons are unaware that there is link between faecal contamination of well water and the occurrence of intestinal worms, diarrheic diseases, schistosomiasis, and skin troubles among others (Olabisi et al., 2008). Most of the bacteria, viruses, parasites, and fungi that contaminate well water come from faecal material of humans and other animals (Olatunji and Oladepo, 2013). Common bacterial contaminants include E. coli, Salmonella, Shigella, and Campylobacter jejuni. Common viral contaminants include norovirus, sapovirus, rotavirus, enteroviruses, and hepatitis $\mathrm{A}$ and $\mathrm{E}$. Parasites include Giardia lamblia, Cryptosporidium, Cyclospora cayetanensis, and Microsporidia (Olabisi et al., 2008)

Human and livestock waste excreted in pit latrines, over land or in open-pit wells, called 'scoop wells', may contain worms, protozoa, bacteria and viruses that, if consumed, can lead to the contraction of hepatitis, typhoid, cholera and a variety of diarrhoeal diseases. Wells and springs harvesting shallow groundwaters are generally protected from these pathogens by a granular soil matrix which both filters bacteria, protozoa and worms due to their relatively large diameter $(>0.5 \mathrm{~mm})$ in relation to the aquifer material, and adsorbs smaller viruses on account of their strong, negative surface charge. Despite this cleansing capacity, the presence of coliform group of bacteria in groundwater indicates that faecal contamination has occurred (Lewis et al., 1980). High nitrate concentrations also indicate contamination from sewage sources since nitrogenous material, which is uncommon to the subsurface mineralogy, forms a significant component of human and animal waste, and is oxidised to nitrate under the aerobic conditions of shallow groundwaters. The risks associated with elevated nitrate levels (>50mg/L) include methaemoglobinaemia (blue baby syndrome) in young infants and the 
development of gastric cancer (WHO, 1996).

\section{Use of coliforms as indicators of water pollution}

A variety of microorganisms are found in water, including pathogenic and non-pathogenic species. Nonpathogenic microorganisms may cause taste and odour problems with water supplies, which can influence use of the water for consumption, but the principal concern for microbiological quality is contamination by pathogenic species (Dagnew et al., 2010). Pathogens found in drinking-water include species of bacteria, viruses, protozoa and helminths.

Coliform bacteria are mainly a group of intestinal bacteria used as indicators to determine if water is acceptable for human consumption. Coliforms may not likely cause illnesses. However, the presence of coliforms in drinking water indicates the presence of disease-causing organisms (Chukwurah, 2006; Nwachukwu and Otokunefor, 2006). The broader group of coliforms, known as total coliforms, is also used to monitor water quality. They are aerobic or facultatively aerobic lactose fermenting gram negative rods which include Escherichia coli, Klebsiella pneumoniae and Enterobacter aerogenes (Rajendran et al., 2006). These bacteria are very sensitive to chlorine and their presence in chlorinated water implies the chlorination was ineffective and that the water may be unsafe to drink (Dagnew et al., 2010).

The use of normal intestinal organisms as indicators of faecal pollution is universally accepted for monitoring and assessing the microbiological safety of water supplies (Dissanayake et al., 2004). The main bacteria of concern in water include Salmonella sp., Shigella sp., Escherichia coli and Vibrio cholera (Rajendran et al., 2006). The presence of faecal coliforms or $E$. coli has been widely used as an indicator for the presence of any of these waterborne pathogens (Okafor, 1985; Okpokwasili and Akujobi, 1996; Ibe and Okplenye, 2005; Kelly et al., 1997; Rajendran et. al., 2006).

The World Health Organization (WHO) recommends that no faecal coliform be present in $100 \mathrm{~mL}$ of drinking water (APHA, 1998). Since identifying pathogenic organisms in the water could be extremely difficult and unreliable, the presence of the indicator organisms, which may be associated with pathogenic organisms, is usually determined. Thus, the presence of $E$. coli; a common intestinal bacterium, indicates presence of recent faecal contamination and the possibility of contamination by pathogenic microorganisms (Rajendran et. al., 2006).

\section{Materials and methods}

\section{Study area}

Akure is the capital city of Ondo State in the south-western region of Nigeria which lies between latitude 70 16' $48^{\prime \prime} \mathrm{N}$ and longitude $5^{\circ} 14^{\prime} 41^{\prime \prime} \mathrm{E}$ of the equator. The climatic condition of Akure follows the pattern of south-western Nigeria where the climate is influenced mainly by the rain-bearing southwest monsoon winds from the ocean and the dry northwest winds from the Sahara Desert. High temperatures and high humidity also characterize the climate. There are two distinct seasons, the rainy and dry seasons. The rainy season lasts for about seven months (April to October). The rainfall is about $1,524 \mathrm{~mm}$ per year. The atmospheric temperature ranges between $25{ }^{\circ} \mathrm{C}$ and $32{ }^{\circ} \mathrm{C}$ and a mean annual relative humidity of about $80 \%$.

The soil is made up of ferruginous tropical soils. Crystalline acid rocks constitute the main parent material of these soils. The main features include a sandy surface horizon underlain by a weakly developed clayey, mottled and occasionally concretionary sub-soil. The soil is however liable to erosion and occasional water logging as a 
result of the clay sub-soil. The soils have an exceptional clayey texture, but combine good drainage and aeration with good properties of moisture and nutrient retention.

\section{Selection of sampling points}

Selection of sampling points is vital during water quality investigation and it is considered more important than actual chemical analysis of water. It was purported that an effective sampling programme entails the selection of sampling points in line with objectives of the study. As such, well waters that are used for domestic purposes in twenty different households were selected for this experiment. It was ensured that the selected households had sewage pits for the disposal of their sewages. An initial assessment of sources of both natural and man-made pollutants, factors that promote contamination of well water and the characteristics of the wells and well areas was carried out prior research. Additionally, substantial information on population density around each water source and behavioural aspects of people was also evaluated (Khalid et al., 2011).

\section{Map of the study sites}

The coordinates of wells and sewage pits at the different study sites were used in generating maps showing the areas. The locations of the wells illustrated on the map (Figure 1) shows a random distribution of the sampled wells around major residential areas of the city. The distribution of the sewage pits (Figure 1) also followed a randomised pattern; their proximity can be seen as some of the points overlapped when represented.

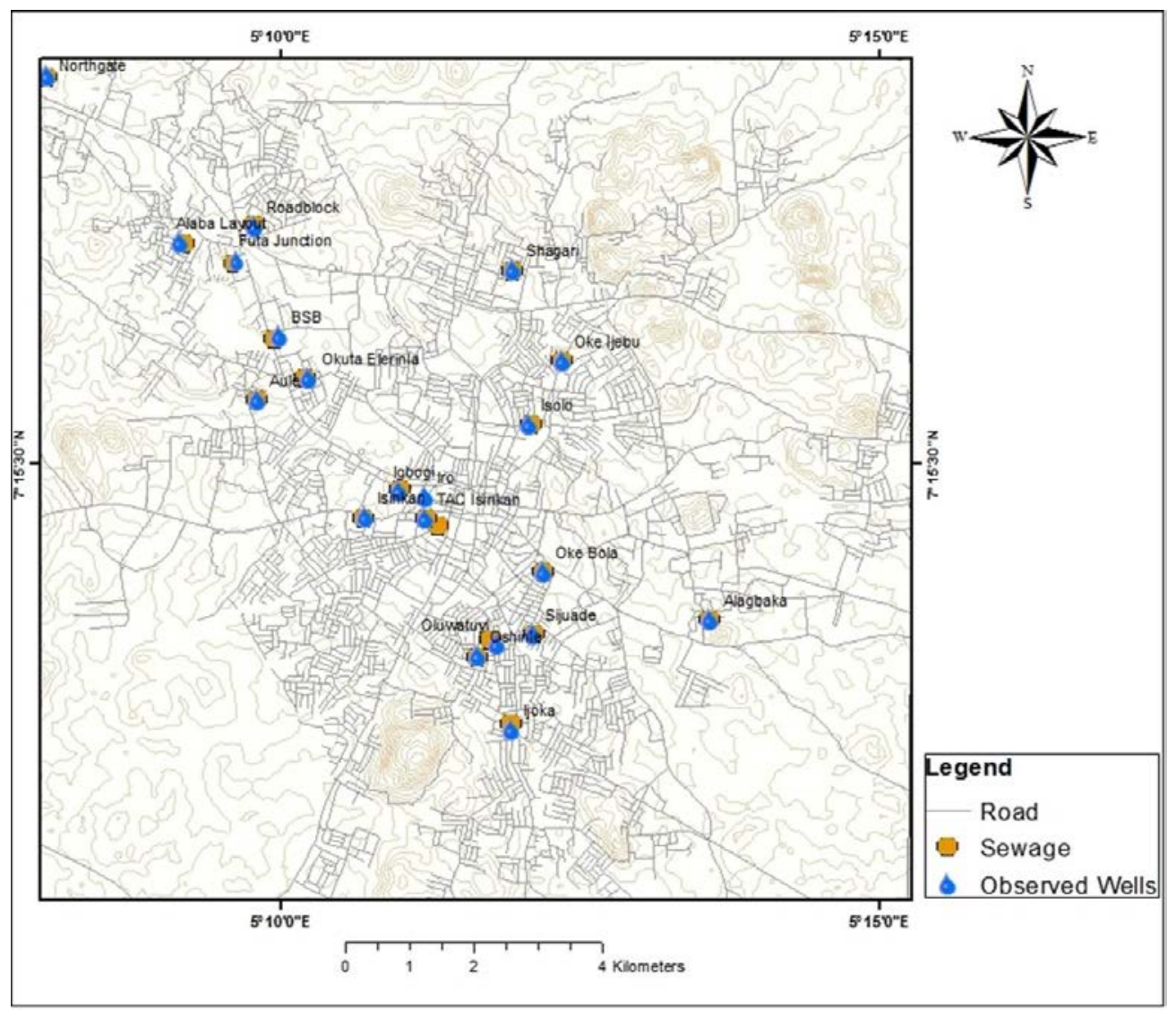

Figure 1. Map of the study area showing the location of the sampled wells and sewage pits at in Akure, Ondo State. 


\section{Sample collection}

20 well water samples were collected in three replicates from wells in different areas of Akure for bacteriological and physicochemical analyses. Water samples were collected in the month of March (Bayode et al., 2012) and July as representatives of the dry and rainy seasons respectively. Collection of samples was done aseptically into sterile $5 \mathrm{~mL}$ serum bottles and $1 \mathrm{~L}$ pet bottles that were fitted with screw caps and properly labeled. Samples were transported to the laboratory on ice in order to maintain the microbial population and were processed for microbial presence within $24 \mathrm{~h}$.

\section{Determination of coordinates for wells and sewage pits coordinates for map generation}

The locations of the wells and septic tanks were determined using a Global Positioning System (GPS) device (Adetunji and Odetokun, 2011). The recorded coordinates were used in generating maps for the study sites.

Measurement of well depth, height of water table and distance between wells and sewage pits

A measuring tape to which a weight was attached was used to measure the depth of well and the height of the water table of the wells. The end of the measuring tape to which a weight was attached was let down into the well gradually, the measurement for water table level was recorded when it touched the water surface while the height of well was recorded when the weight hits the bottom of the well. Distances between the septic tanks and wells were also measured using a measuring tape.

\section{Analysis of soil profile}

Soils around sampled wells were collected using soil auger, which was dug into soil up to $5 \mathrm{~cm}$ deep. Collected soil samples were transported to the laboratory in ziplock cellophane bag where they were instantly evenly mixed with water inside the measuring cylinder. The set up was allowed to settle for $24 \mathrm{~h}$ in order to get the division of the various layers in the soil formation. Percentage of the soil components such as sand and clay were used in the determination of soil type. Floor covering and well age were determined and also taken into account in the the assessment of the water quality.

\section{Physicochemical analyses}

pH. The pH of all water samples was taken at the time of collection by using portable battery operated $\mathrm{pH}$ meter. The pHmetre was calibrated using a pH 7 buffer solution before each measurement. It was afterwards dipped in the water samples and left till the indicated value remained constant for about $1 \mathrm{~min}$. The pHmeter was cleaned with tissue paper after each measurement.

Temperature. A portable thermometer was used in measuring the temperature of all water samples. The thermometer was dipped in the water samples and reading was taken after the indicated value remained constant for about $1 \mathrm{~min}$. The thermometer was cleaned with tissue paper after each measurement.

Dissolved oxygen $\left(\mathrm{DO}_{2}\right)$. The dissolved oxygen $\left(\mathrm{DO}_{2}\right)$ of the water samples was measured using precalibrated dissolved oxygen meter. The beaker and electrode were rinsed several times with the water sample to be tested in order to ensure accurate result. The metre was dipped in water sample and the reading was noted after the indicated value remained constant for about $1 \mathrm{~min}$. It was cleaned with tissue paper after each measurement.

Electrical Conductivity (EC). The conductivity (or specific 
conductance) of an electrolyte solution is a measure of its ability to conduct electricity. The electrical conductivity of the water samples was measured using a portable battery operated conductivity metre. The conductivitymeter was dipped in water sample and the reading was noted after the indicated value remained constant for about 1 minute. It was cleaned with tissue paper after each measurement.

\section{Microbiological analysis}

Test for total coliform. To check

for the Total coliform in the water samples, $0.1 \mathrm{~mL}$ of water was plated in a Petri dish containing MacConkey Agar as the growth medium. It was then incubated at $37{ }^{\circ} \mathrm{C}$ for $24 \mathrm{~h}$ after which the observed colonies were counted. This experiment was replicated three times for each well water sample. The appearance of a pink to dark red indicated the presence of coliforms.

Test for faecal coliform. Plate containing Eosin Methylene Blue Agar was inoculated with $0.1 \mathrm{~mL}$ of well water which was then incubated for $24 \mathrm{~h}$ at $44^{\circ} \mathrm{C}$; this was replicated three times for each well water sample. Bacterial cells developed into a separate colony of with metallic sheen which was counted to obtain the viable cell count. The analysis of water sample was carried out within twenty four hours of collection.

\section{Questionnaires and data record forms}

The use of data record forms and questionnaires was employed in the overall evaluation of the sanitary conditions of the wells and their environments. Questionnaires (200) were administered to inhabitants of study area who use well water to obtain information on various uses of water, hygiene and sanitation practices and assess their knowledge of water borne diseases. They were also used in the risk assessment of the sample sites. Questionnaires and record data forms used were modified from Ince et al. (2010).

\section{Statistical analyses of data}

All necessary analyses were carried out using Statistical Package for Social Sciences (SPSS) version 20.0. Oneway ANOVA was used to compare the total and faecal coliform count of different wells while the T-test was used to compare physicochemical parameters and coliform counts for rainy and dry season. A correlation analysis was also done to establish the degree of relationship between the coliform counts and the distances between the sewage pits and wells and other important parameters (Adetunji and Odetokun, 2011).

\section{Results}

\section{sampled wells \\ General characteristics of}

Table 2 shows the characteristics of the wells under studied. Out of the twenty wells under study, 90\% (18) were ringed while $10 \%$ (2) were not ringed. All wells in the study sites were elevated above the ground level. Ninety percent (18) of wells sampled were covered while $10 \%$ (2) had no covering. Percentage of wells sited in areas with cemented floor covering was 55\% (11), while $45 \%$ (9) had no cemented floor covering around them. Forty-five percent (9) of the wells were located up-gradient sewage pits while $55 \%$ (11) were located down-gradient the sewage pits. Sixty five percent (13) of the understudied wells were located in sandy soil dominant areas while 35\% (7) were sited in areas with more clay soil materials (Figure 2). 
Table 2. General characteristics of wells in study sites.

\begin{tabular}{|c|c|c|c|c|c|c|}
\hline \multirow[b]{2}{*}{$\begin{array}{l}\text { Well } \\
\text { site }\end{array}$} & \multicolumn{6}{|c|}{ Well Characteristics } \\
\hline & $\begin{array}{l}\text { Ringed/ } \\
\text { Unringed }\end{array}$ & $\begin{array}{c}\text { Elevated/ } \\
\text { Not } \\
\text { elevated }\end{array}$ & $\begin{array}{c}\text { Covered/ } \\
\text { Uncovered }\end{array}$ & $\begin{array}{c}\text { Well Floor } \\
\text { area }\end{array}$ & $\begin{array}{c}\text { Orientation } \\
\text { to sewage } \\
\text { pit }\end{array}$ & $\begin{array}{c}\text { Main soil } \\
\text { type in } \\
\text { well area }\end{array}$ \\
\hline $\mathrm{AA}$ & Ringed & Elevated & Covered & Cemented & $\begin{array}{l}\text { down- } \\
\text { gradient }\end{array}$ & Clay \\
\hline $\mathrm{AL}$ & Ringed & Elevated & Covered & Cemented & $\begin{array}{l}\text { down- } \\
\text { gradient }\end{array}$ & Sandy \\
\hline $\mathrm{AU}$ & Ringed & Elevated & Covered & Cemented & up-gradient & Clay \\
\hline BSB & Ringed & Elevated & Covered & $\begin{array}{l}\text { Not } \\
\text { cemented }\end{array}$ & $\begin{array}{l}\text { down- } \\
\text { gradient }\end{array}$ & Sandy \\
\hline $\mathrm{FJ}$ & Ringed & Elevated & Covered & $\begin{array}{l}\text { Not } \\
\text { cemented }\end{array}$ & up-gradient & Sandy \\
\hline $\mathrm{IG}$ & Ringed & Elevated & Covered & Cemented & up-gradient & Sandy \\
\hline IJ & Ringed & Elevated & Uncovered & $\begin{array}{l}\text { Not } \\
\text { cemented }\end{array}$ & $\begin{array}{l}\text { down- } \\
\text { gradient }\end{array}$ & Sandy \\
\hline IR & Ringed & Elevated & Covered & Cemented & $\begin{array}{l}\text { down- } \\
\text { gradient }\end{array}$ & Clay \\
\hline IS & Ringed & Elevated & Covered & Cemented & up-gradient & Sandy \\
\hline ISL & Ringed & Elevated & Covered & $\begin{array}{l}\text { Not } \\
\text { cemented }\end{array}$ & $\begin{array}{l}\text { down- } \\
\text { gradient }\end{array}$ & Sandy \\
\hline NO & Ringed & Elevated & Uncovered & Cemented & up-gradient & Clay \\
\hline OB & Unringed & Elevated & Covered & $\begin{array}{l}\text { Not } \\
\text { cemented }\end{array}$ & $\begin{array}{l}\text { down- } \\
\text { gradient }\end{array}$ & Sandy \\
\hline $\mathrm{OE}$ & Ringed & Elevated & Covered & Cemented & $\begin{array}{l}\text { down- } \\
\text { gradient }\end{array}$ & Clay \\
\hline 00 & Ringed & Elevated & Covered & $\begin{array}{l}\text { Not } \\
\text { cemented }\end{array}$ & $\begin{array}{l}\text { down- } \\
\text { gradient }\end{array}$ & Sandy \\
\hline $\mathrm{OL}$ & Ringed & Elevated & Covered & Cemented & up-gradient & Sandy \\
\hline OS & Unringed & Elevated & Covered & $\begin{array}{l}\text { Not } \\
\text { cemented }\end{array}$ & $\begin{array}{l}\text { down- } \\
\text { gradient }\end{array}$ & Sandy \\
\hline $\mathrm{RB}$ & Ringed & Elevated & Covered & Cemented & up-gradient & Clay \\
\hline $\mathrm{SH}$ & Ringed & Elevated & Covered & Cemented & up-gradient & Sandy \\
\hline SJ & Ringed & Elevated & Covered & $\begin{array}{l}\text { Not } \\
\text { cemented }\end{array}$ & $\begin{array}{l}\text { down- } \\
\text { gradient }\end{array}$ & Clay \\
\hline $\mathrm{TI}$ & Ringed & Elevated & Covered & $\begin{array}{l}\text { Not } \\
\text { cemented }\end{array}$ & up-gradient & Sandy \\
\hline
\end{tabular}

\section{in study sites \\ Well water withdrawal method}

Water withdrawal method was different across all sampled wells (Table 3 ). Water is obtained from 65\% (13) of wells by fetching with buckets, while water is exclusively pumped out from $10 \%$ (2) of the wells studied. However, water is withdrawn from $25 \%$ (5) of the wells through pumping and fetching (Figure 3). 


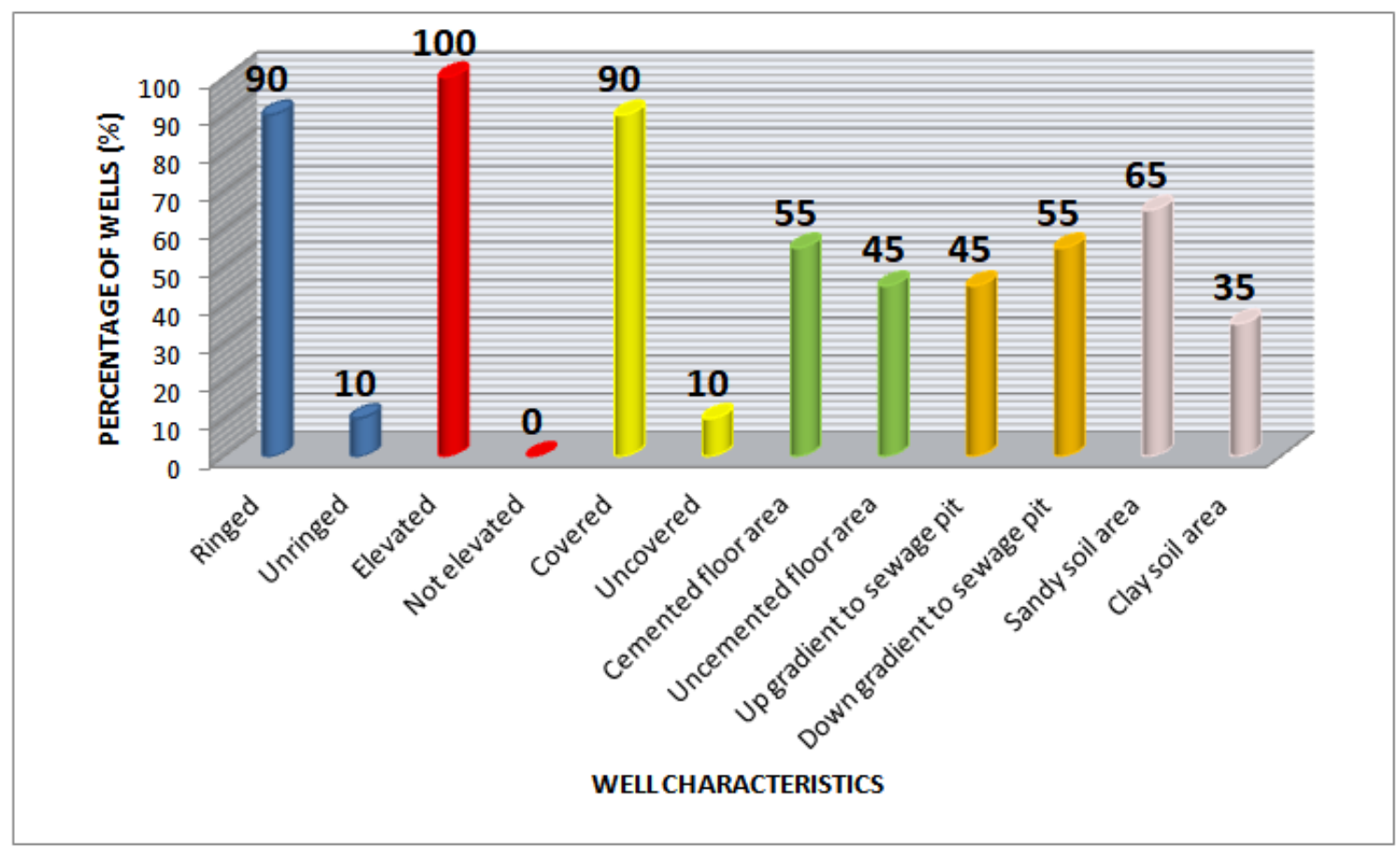

Figure 2: General characteristics of wells in study sites

Table 3. Drought periods and water withdrawal methods from wells.

\begin{tabular}{|l|c|c|}
\hline Well site & Water withdrawal method & Drought period \\
\hline AA & Pumped & Yearly \\
\hline AL & Fetched & Never \\
\hline AU & Fetched, Pumped & Every 4 years \\
\hline BSB & Fetched & Never \\
\hline FJ & Fetched & Never \\
\hline IG & Fetched & Every 2 years \\
\hline IJ & Fetched & Yearly \\
\hline IR & Fetched & Yearly \\
\hline IS & Fetched, Pumped & Never \\
\hline ISL & Fetched & Never \\
\hline NO & Fetched, Pumped & Yearly \\
\hline OB & Fetched & Yearly \\
\hline OE & Pumped & Never \\
\hline OO & Fetched & Yearly \\
\hline OL & Fetched & Yearly \\
\hline OS & Fetched & Yearly \\
\hline RB & Fetched & Never \\
\hline SH & Fetched, Pumped & Yearly \\
\hline SJ & Fetched & Yearly \\
\hline TI & Fetched & Never \\
\hline
\end{tabular}




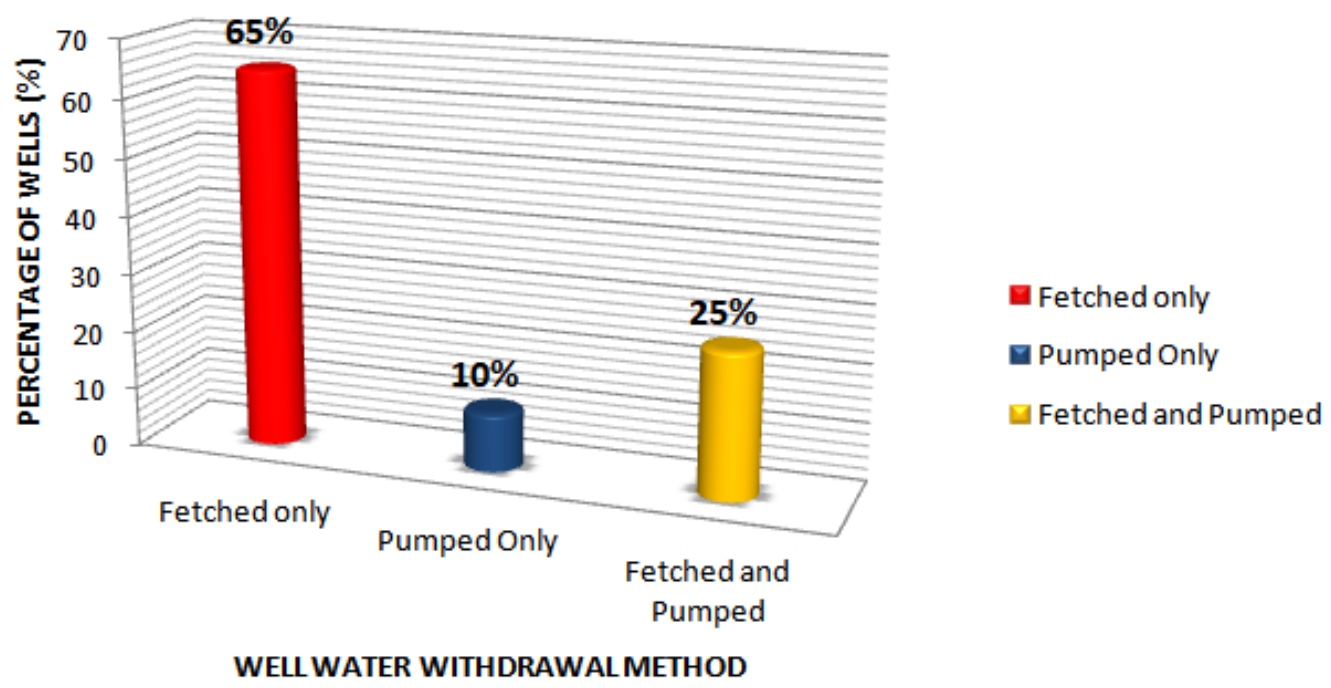

Figure 3. Water withdrawal method from wells.

\section{study sites}

\section{Drought periods of wells in}

Drought period of the wells under study is shown on Table 3. It was revealed that $50 \%$ (10) of the wells dry up yearly, 5\% (1) dry up every 2 years, another 5\% (1) dry up every 4 years while a total of $40 \%$ (8) were reported to never dry up (Figure 4).

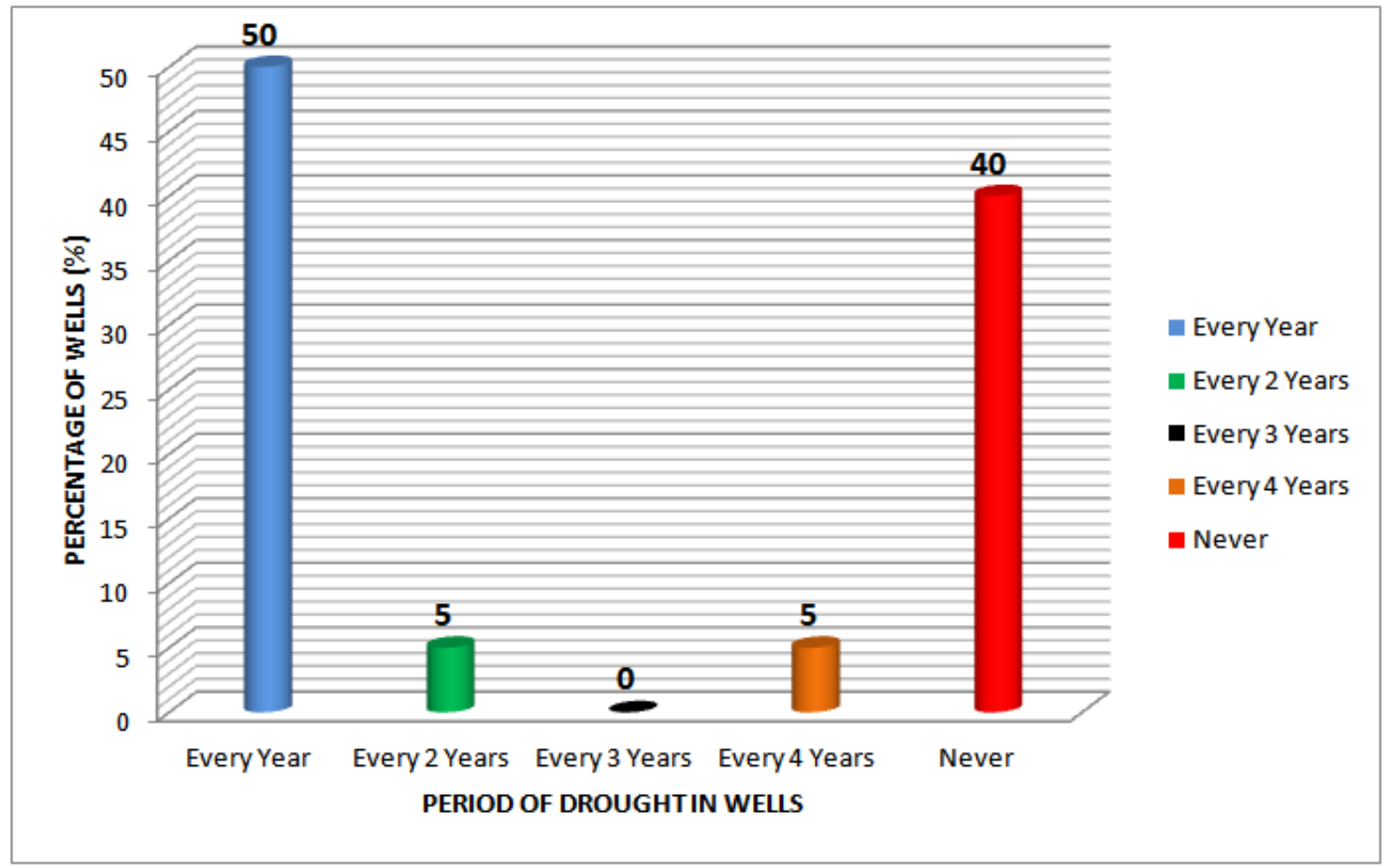

Figure 4. Drought periods of wells in study sites. 


\section{Sanitation assessment of wells in study sites}

All wells were vulnerable to contamination through natural and anthropogenic sources. The sanitation grading employed in the questionnaire showed that $50 \%$ (10) of the wells have a low risk of possible contamination while the other $50 \%$ (10) were at a medium risk of being contaminated.

\section{well water}

Physicochemical properties of

pH. The $\mathrm{pH}$ of the observed water samples in the dry season (Table 4) ranged between 5.5 and 7.5 with a mean of $6.23 \pm 0.11$. Water sample from the well in NO had the lowest pH $(5.5 \pm 0.06)$ which was not significantly different
$(\mathrm{P}<0.05)$ from the $\mathrm{pH}$ of water from wells in AA (5.6 \pm 0.06$)$, FJ (5.6 \pm 0.06$)$, OB $(5.6 \pm 0.06)$ and OI $(5.7 \pm 0.06)$. The highest $\mathrm{pH}$ of well water in the dry season was obtained from the well at RB $(7.5 \pm 0.06)$. It was significantly different $(\mathrm{P}<0.05)$ from the $\mathrm{pH}$ of other well waters. The $\mathrm{pH}$ of the water samples ranged between 4.7 and 7.2 in the rainy season (Table 5), with a mean of $5.91 \pm 0.14$ which is lower than that of the dry season $(6.23 \pm 0.11)$ (Table 4). Water sample from the well in NO had the lowest $\mathrm{pH}(4.6 \pm 0.06)$ while the highest $\mathrm{pH}(7.2 \pm 0.06)$ was observed in the water sample from the well at RB. The $\mathrm{pH}$ of water samples from these sites were both significantly different $(P<0.05)$ from the others.

Table 4. Physicochemical properties of well water in dry season.

\begin{tabular}{|c|c|c|c|c|}
\hline Sites & $\begin{array}{l}\text { Mean Temp }\left({ }^{\circ} \mathrm{C}\right) \\
\pm \mathrm{SE}\end{array}$ & Mean $\mathrm{pH} \pm \mathrm{SE}$ & $\begin{array}{c}\text { Mean Dissolved } \\
\text { Oxygen }(\mathrm{mg} / \mathrm{L}) \pm \mathrm{SE}\end{array}$ & $\begin{array}{c}\text { Mean Electrical } \\
\text { Conductivity } \\
(\mu \mathrm{S} / \mathrm{cm}) \pm \mathrm{SE}\end{array}$ \\
\hline $\mathrm{AA}$ & $27.70 \pm 0.06^{\mathrm{cd}}$ & $5.60 \pm 0.06^{\mathrm{ab}}$ & $1.56 \pm 0.01^{\mathrm{d}}$ & $2.03 \times 10^{2} \pm 0.58^{\mathrm{e}}$ \\
\hline AL & $27.40 \pm 0.06^{\mathrm{bc}}$ & $6.50 \pm 0.06^{\mathrm{efg}}$ & $2.30 \pm 0.06^{\mathrm{f}}$ & $3.38 \times 10^{2} \pm 0.58^{\mathrm{k}}$ \\
\hline $\mathrm{AU}$ & $27.50 \pm 0.06^{\mathrm{bcd}}$ & $6.20 \pm 0.06^{\text {cde }}$ & $0.72 \pm 0.01^{\mathrm{b}}$ & $3.91 \times 10^{2} \pm 0.58^{1}$ \\
\hline BSB & $27.70 \pm 0.06^{\mathrm{cd}}$ & $6.30 \pm 0.06^{\mathrm{def}}$ & $4.84 \pm 0.0^{1 \mathrm{k}}$ & $3.40 \times 10^{2} \pm 0.58^{\mathrm{k}}$ \\
\hline FJ & $27.90 \pm 0.06^{\mathrm{d}}$ & $5.60 \pm 0.06^{\mathrm{ab}}$ & $2.56 \pm 0.01^{\mathrm{g}}$ & $2.24 \times 10^{2} \pm 0.58^{g}$ \\
\hline IG & $29.10 \pm 0.06^{\mathrm{e}}$ & $6.50 \pm 0.06^{\mathrm{efg}}$ & $1.53 \pm 0.01^{\mathrm{d}}$ & $2.67 \times 10^{2} \pm 0.58^{\mathrm{h}}$ \\
\hline IJ & $29.00 \pm 0.06^{\mathrm{e}}$ & $6.40 \pm 0.06^{\text {defg }}$ & $1.10 \pm 0.06^{c}$ & $2.87 \times 10^{2} \pm 0.58^{\mathrm{i}}$ \\
\hline IR & $27.60 \pm 0.06^{\mathrm{cd}}$ & $6.20 \pm 0.06^{\text {cde }}$ & $5.60 \pm 0.06^{1}$ & $9.09 \times 10^{2} \pm 0.58^{p}$ \\
\hline IS & $27.60 \pm 0.06^{\mathrm{cd}}$ & $6.60 \pm 0.06^{\mathrm{fg}}$ & $2.30 \pm 0.06^{\mathrm{f}}$ & $2.27 \times 10^{2} \pm 0.58^{g}$ \\
\hline ISL & $29.10 \pm 0.06^{\mathrm{e}}$ & $6.70 \pm 0.06^{\mathrm{g}}$ & $0.18 \pm 0.01^{\mathrm{a}}$ & $8.82 \times 10^{2} \pm 0.58^{\circ}$ \\
\hline NO & $26.70 \pm 0.06^{\mathrm{a}}$ & $5.50 \pm 0.06^{\mathrm{a}}$ & $4.01 \pm 0.01^{\mathrm{j}}$ & $0.76 \times 10^{2} \pm 0.58^{\mathrm{a}}$ \\
\hline $\mathrm{OB}$ & $28.90 \pm 0.06^{\mathrm{e}}$ & $5.60 \pm 0.06^{\mathrm{ab}}$ & $2.58 \pm 0.01^{\mathrm{g}}$ & $8.48 \times 10^{2} \pm 0.58^{\mathrm{n}}$ \\
\hline $\mathrm{OE}$ & $27.60 \pm 0.06^{\mathrm{cd}}$ & $6.60 \pm 0.06 \mathrm{fg}$ & $0.12 \pm 0.01^{\mathrm{a}}$ & $1.52 \times 10^{2} \pm 0.58^{d}$ \\
\hline 00 & $27.60 \pm 0.06^{\mathrm{cd}}$ & $5.70 \pm 0.06^{\mathrm{ab}}$ & $2.77 \pm 0.01^{\mathrm{h}}$ & $9.10 \times 10^{2} \pm 0.58^{p}$ \\
\hline $\mathrm{OL}$ & $27.80 \pm 0.06^{\mathrm{d}}$ & $6.10 \pm 0.06^{\mathrm{cd}}$ & $0.15 \pm 0.01^{\mathrm{a}}$ & $4.83 \times 10^{2} \pm 0.58^{\mathrm{m}}$ \\
\hline OS & $27.50 \pm 0.06^{\mathrm{bcd}}$ & $5.90 \pm 0.06^{\mathrm{bc}}$ & $1.59 \pm 0.01^{\mathrm{de}}$ & $2.02 \times 10^{2} \pm 0.58^{\mathrm{e}}$ \\
\hline $\mathrm{RB}$ & $27.20 \pm 0.06^{\mathrm{b}}$ & $7.50 \pm 0.06^{\mathrm{h}}$ & $0.05 \pm 0.01^{\mathrm{a}}$ & $3.31 \times 10^{2} \pm 0.58^{j}$ \\
\hline SH & $27.80 \pm 0.09^{\mathrm{d}}$ & $5.90 \pm 0.06^{b c}$ & $3.78 \pm 0.01^{\mathrm{i}}$ & $2.08 \times 10^{2} \pm 0.58^{\mathrm{f}}$ \\
\hline SJ & $27.50 \pm 0.06^{\mathrm{bcd}}$ & $6.50 \pm 0.06^{\mathrm{efg}}$ & $1.73 \pm 0.01^{\mathrm{e}}$ & $1.03 \times 10^{2} \pm 0.58^{\mathrm{b}}$ \\
\hline $\mathrm{TI}$ & $28.80 \pm 0.06^{\mathrm{e}}$ & $6.40 \pm 0.06^{\text {defg }}$ & $1.72 \pm 0.01^{\mathrm{e}}$ & $1.40 \times 10^{2} \pm 0.58^{\mathrm{c}}$ \\
\hline
\end{tabular}

*Values with the same letter along the same column are not significantly different at $\mathrm{P}<0.05$ using Tukey's post-hoc test.

Temperature. The physicchemical properties of the well waters studied during the dry season are presented on Table 4. The temperature ranged between $26.7^{\circ} \mathrm{C}$ and $29.1{ }^{\circ} \mathrm{C}$ with a mean of $27.9^{\circ} \mathrm{C} \pm 0.16$. The lowest dry 
season temperature was observed in the water from the well in NO $\left(26.7^{\circ} \mathrm{C} \pm 0.06\right)$ although it was not significantly different $(\mathrm{P}<0.05)$ from those of $\mathrm{AL} \quad\left(27.4^{\circ} \mathrm{C} \pm 0.06\right), \quad \mathrm{AU}$ $\left(27.5^{\circ} \mathrm{C} \pm 0.06\right)$, IR $\left(27.6^{\circ} \mathrm{C} \pm 0.06\right)$, IS $\left(27.6^{\circ} \mathrm{C} \pm 0.06\right)$, OE $\left(27.6^{\circ} \mathrm{C} \pm 0.06\right)$, OI $\left(27.6^{\circ} \mathrm{C} \pm 0.06\right)$, OS $\left(27.5^{\circ} \mathrm{C} \pm 0.06\right)$, RB $\left(27.2^{\circ} \mathrm{C} \pm 0.06\right)$, and SJ $\left(27.5^{\circ} \mathrm{C} \pm 0.06\right)$. The highest dry season well water temperature $29.1^{\circ} \mathrm{C} \pm 0.06$ was observed in the water from the wells in IG and ISL. The temperature was however not significantly different $(\mathrm{P}<0.05)$ from those of FJ $\quad\left(27.9^{\circ} \mathrm{C} \pm 0.06\right)$, IJ $\left(29.0^{\circ} \mathrm{C} \pm 0.06\right), \mathrm{OB}\left(28.9^{\circ} \mathrm{C} \pm 0.06\right)$ and TI $\left(28.8^{\circ} \mathrm{C} \pm 0.06\right)$.

The rainy season temperatures of the well water samples was generally higher (Table 5) ranging between $26.7^{\circ} \mathrm{C}$ and $30.1{ }^{\circ} \mathrm{C}$ with a mean of $28.5^{\circ} \mathrm{C} \pm 0.20$ which was higher than that of the dry season $\left(27.9^{\circ} \mathrm{C} \pm 0.16\right)$. The lowest well water temperature for the rainy season was observed in the water sample from NO $\left(26.7^{\circ} \mathrm{C} \pm 0.06\right)$ while the highest water temperature was observed in the sample from $\mathrm{TI}\left(30.1^{\circ} \mathrm{C} \pm 0.06\right)$. They were both significantly different $(\mathrm{P}<0.05)$ from the temperature of other water samples.

Table 5. Physicochemical properties of well water in rainy season.

\begin{tabular}{|c|c|c|c|c|}
\hline Sites & $\begin{array}{c}\text { Mean Temp }\left({ }^{\circ} \mathrm{C}\right) \\
\pm \mathrm{SE}\end{array}$ & Mean $\mathrm{pH} \pm \mathrm{SE}$ & $\begin{array}{c}\text { Mean Dissolved } \\
\text { Oxygen }(\mathrm{mg} / \mathrm{L}) \pm \mathrm{SE}\end{array}$ & $\begin{array}{l}\text { Mean Electrical } \\
\text { Conductivity } \\
(\mu \mathrm{S} / \mathrm{cm}) \pm \mathrm{SE}\end{array}$ \\
\hline $\mathrm{AA}$ & $28.60 \pm 0.06^{\mathrm{ef}}$ & $5.10 \pm 0.06^{b}$ & $2.78 \pm 0.01^{\mathrm{e}}$ & $2.84 \times 10^{2} \pm 0.58^{d}$ \\
\hline $\mathrm{AL}$ & $27.20 \pm 0.06^{b}$ & $5.90 \pm 0.06^{d}$ & $2.30 \pm 0.06^{\mathrm{d}}$ & $4.65 \times 10^{2} \pm 0.58^{\mathrm{i}}$ \\
\hline $\mathrm{AU}$ & $28.90 \pm 0.06^{\mathrm{fg}}$ & $6.50 \pm 0.06^{f}$ & $3.63 \pm 0.01^{\mathrm{i}}$ & $4.05 \times 10^{2} \pm 0.58^{h}$ \\
\hline $\mathrm{BSB}$ & $28.50 \pm 0.06^{\mathrm{e}}$ & $6.00 \pm 0.06^{\mathrm{de}}$ & $6.72 \pm 0.01^{\circ}$ & $4.96 \times 10^{2} \pm 0.58 j$ \\
\hline FJ & $28.00 \pm 0.06^{\mathrm{cd}}$ & $5.20 \pm 0.06^{b c}$ & $3.65 \pm 0.01^{\mathrm{i}}$ & $2.84 \times 10^{2} \pm 0.58^{\mathrm{d}}$ \\
\hline IG & $29.40 \pm 0.06^{\mathrm{hi}}$ & $6.10 \pm 0.06^{\mathrm{def}}$ & $3.15 \pm 0.01^{f}$ & $3.27 \times 10^{2} \pm 0.58^{\mathrm{e}}$ \\
\hline IJ & $29.50 \pm 0.06^{i}$ & $6.30 \pm 0.06^{\mathrm{ef}}$ & $2.01 \pm 0.01^{\mathrm{c}}$ & $3.98 \times 10^{2} \pm 0.58^{\mathrm{fg}}$ \\
\hline IR & $28.60 \pm 0.06^{\mathrm{ef}}$ & $6.20 \pm 0.06^{\mathrm{def}}$ & $7.34 \pm 0.01^{p}$ & $1.56 \times 10^{3} \pm 5.77^{n}$ \\
\hline IS & $28.60 \pm 0.06^{\mathrm{ef}}$ & $6.50 \pm 0.06^{\mathrm{f}}$ & $4.04 \pm 0.01^{\mathrm{k}}$ & $4.59 \times 10^{2} \pm 0.58^{\mathrm{i}}$ \\
\hline ISL & $29.10 \pm 0.06^{\mathrm{gh}}$ & $6.20 \pm 0.06^{\mathrm{def}}$ & $1.23 \pm 0.01^{\mathrm{a}}$ & $1.34 \times 10^{3} \pm 5.771$ \\
\hline NO & $26.70 \pm 0.06^{\mathrm{a}}$ & $5.20 \pm 0.06^{\mathrm{bc}}$ & $3.15 \pm 0.01^{\mathrm{f}}$ & $1.32 \times 10^{2} \pm 0.58^{a}$ \\
\hline OB & $28.90 \pm 0.06^{\mathrm{fg}}$ & $4.60 \pm 0.06^{a}$ & $4.87 \pm 0.01^{\mathrm{n}}$ & $1.88 \times 10^{3} \pm 5.77^{\circ}$ \\
\hline $\mathrm{OE}$ & $29.60 \pm 0.06^{\mathrm{i}}$ & $6.30 \pm 0.06^{\mathrm{ef}}$ & $3.42 \pm 0.01^{\mathrm{h}}$ & $2.25 \times 10^{2} \pm 0.58^{b}$ \\
\hline 00 & $27.90 \pm 0.06^{c}$ & $5.20 \pm 0.06^{b c}$ & $4.73 \pm 0.01^{\mathrm{m}}$ & $1.51 \times 10^{3} \pm 5.77 \mathrm{~m}$ \\
\hline $\mathrm{OL}$ & $28.00 \pm 0.06^{\mathrm{cd}}$ & $5.90 \pm 0.06^{\mathrm{d}}$ & $1.65 \pm 0.01^{b}$ & $6.38 \times 10^{2} \pm 0.58^{\mathrm{k}}$ \\
\hline OS & $27.90 \pm 0.06^{c}$ & $5.50 \pm 0.06^{c}$ & $3.38 \pm 0.01^{\mathrm{gh}}$ & $3.92 \times 10^{2} \pm 0.58^{\mathrm{fg}}$ \\
\hline $\mathrm{RB}$ & $28.40 \pm 0.06 \mathrm{e}$ & $7.20 \pm 0.06 \mathrm{~g}$ & $2.03 \pm 0.01^{c}$ & $3.89 \times 10^{2} \pm 0.58^{f}$ \\
\hline $\mathrm{SH}$ & $28.30 \pm 0.06^{\mathrm{de}}$ & $5.50 \pm 0.06^{c}$ & $4.52 \pm 0.01^{1}$ & $3.13 \times 10^{2} \pm 0.58^{\mathrm{e}}$ \\
\hline SJ & $26.90 \pm 0.06^{\mathrm{ab}}$ & $6.40 \pm 0.06^{f}$ & $3.33 \pm 0.01^{\mathrm{g}}$ & $2.42 \times 10^{2} \pm 0.58^{c}$ \\
\hline $\mathrm{TI}$ & $30.10 \pm 0.06^{j}$ & $6.40 \pm 0.06^{\mathrm{f}}$ & $3.92 \pm 0.01^{\mathrm{j}}$ & $4.40 \times 10^{2} \pm 0.58^{\mathrm{h}}$ \\
\hline
\end{tabular}

*Values with the same letter along the same column are not significantly different at $\mathrm{P}<0.05$ using Tukey's post-hoc test.

Dissolved oxygen $\left(\mathrm{DO}_{2}\right)$. The dissolved oxygen values of all well water sampled is presented on Table 4. In the dry season, dissolved oxygen values for observed water samples ranged between
$0.05 \mathrm{mg} / \mathrm{L}$ and $5.6 \mathrm{mg} / \mathrm{L}$, with a mean of $2.06 \mathrm{mg} / \mathrm{L} \pm 0.35$. The lowest $\mathrm{DO}_{2}$ concentration $(0.05 \mathrm{mg} / \mathrm{L} \pm 0.01)$ in the dry season was recorded for the water sample taken from RB well, it was 
however not significantly different $(\mathrm{P}<0.05)$ from that of ISL $(0.18 \mathrm{mg} / \mathrm{L} \pm$ $0.01), \mathrm{OE}(0.12 \mathrm{mg} / \mathrm{L} \pm 0.01)$ and OL $(0.15$ $\mathrm{mg} / \mathrm{L} \pm 0.01)$. The highest concentration of $\mathrm{DO}_{2}(5.60 \mathrm{mg} / \mathrm{L} \pm 0.06)$ in the dry season was observed in the well water from IR which was significantly different $(\mathrm{P}<0.05)$ from those of the other well water samples. With a mean of 3.59 $\mathrm{mg} / \mathrm{L} \pm 0.35$ (Table 6) and a range between $1.23 \mathrm{mg} / \mathrm{L}$ and $7.34 \mathrm{mg} / \mathrm{L}$ (Table 5), the $\mathrm{DO}_{2}$ level of the water samples was generally higher in the rainy season. The lowest $\mathrm{DO}_{2}$ level; 1.23 $\mathrm{mg} / \mathrm{L} \pm 0.01$ in the rainy season was observed in the water sample from the well at ISL while the water sample from the well at IR had the highest $\mathrm{DO}_{2}$ concentration $(7.34 \mathrm{mg} / \mathrm{L} \pm 0.01$ in the rainy season. They were both significantly different $(\mathrm{P}<0.05)$ from the $\mathrm{DO}_{2}$ concentrations of other well water samples.

Table 6. Seasonal variation of physicochemical parameters of well water and comparison with WHO standards.

\begin{tabular}{|c|c|c|c|c|c|c|c|c|}
\hline \multirow[b]{2}{*}{ Parameters } & \multicolumn{3}{|c|}{ Dry Season } & \multicolumn{3}{|c|}{ Rainy Season } & \multicolumn{2}{|c|}{ WHO Standards } \\
\hline & MIN & MAX & $\mathrm{MEAN} \pm \mathrm{SE}$ & MIN & MAX & MEAN $\pm S E$ & $\begin{array}{c}\text { Highest } \\
\text { desirable }\end{array}$ & $\begin{array}{c}\text { Maximum } \\
\text { permissible }\end{array}$ \\
\hline Temperature $\left({ }^{\circ} \mathrm{C}\right)$ & 26.7 & 29.1 & $27.9 \pm 0.16$ & 26.7 & 30.1 & $28.5 \pm 0.20$ & - & - \\
\hline pH & 5.5 & 7.5 & $6.23 \pm 0.11$ & 4.6 & 7.2 & $5.91 \pm 0.14$ & $7.0-8.9$ & $6.5-9.5$ \\
\hline $\begin{array}{l}\text { Dissolved Oxygen } \\
\text { (mg/L) } \\
\text { Electrical }\end{array}$ & 0.1 & 5.6 & $2.06 \pm 0.35$ & 1.23 & 7.34 & $3.59 \pm 0.35$ & 7.5 & 7.5 \\
\hline $\begin{array}{l}\text { Conductivity } \\
(\mu \mathrm{S} / \mathrm{cm})\end{array}$ & 76 & $910^{*}$ & $376 \pm 62.59$ & 132 & $1,880^{*}$ & $608.95 \pm 114.95$ & 900 & 1,200 \\
\hline $\begin{array}{l}\text { Total Coliform } \\
\text { (cfu/100 mL) }\end{array}$ & $55^{*}$ & $8479^{*}$ & $547.3 \pm 417.80$ & $12^{*}$ & $94,500^{*}$ & $16,933.0 \pm 6,737.64$ & 0 & 0 \\
\hline $\begin{array}{l}\text { Faecal Coliform } \\
\text { (cfu/100mL) }\end{array}$ & $12^{*}$ & $229^{*}$ & $43.4 \pm 10.88$ & $10^{*}$ & $23,600^{*}$ & $2,926.8 \pm 1,387.04$ & 0 & 0 \\
\hline
\end{tabular}

MIN=Minimum; MAX=Maximum; SE = Standard Error; WHO=World Health Organisation.

*Values higher than WHO Standards.

Electrical conductivity (EC). In the dry season, the EC value of the well waters (Table 4) ranged between $0.76 \mathrm{x}$ $10^{2} \mu \mathrm{S} / \mathrm{cm}$ and $9.10 \times 10^{2} \mu \mathrm{S} / \mathrm{cm}$ with a mean of $3.76 \times 10^{2} \mu \mathrm{S} / \mathrm{cm} \pm 62.59$ (Table 6). Well water sample from NO had the lowest EC value $\left(0.76 \times 10^{2} \mu \mathrm{S} / \mathrm{cm} \pm 0.58\right)$ which was significantly different from the others while the highest EC value $\left(9.10 \times 10^{2} \mu \mathrm{S} / \mathrm{cm} \pm 0.58\right)$ was observed in well water from OI, this was however not significantly different $(\mathrm{P}<0.05)$ from that of IR which was $9.09 \times 10^{2} \mu \mathrm{S} / \mathrm{cm} \pm$ 0.58 . The EC of well water sample ranged between $1.32 \times 10^{2} \mu \mathrm{S} / \mathrm{cm}$ and $1.88 \times 10^{3}$ $\mu \mathrm{S} / \mathrm{cm}$ in the rainy season (Table 5 ). With a mean of $5.01 \times 10^{2} \mu \mathrm{S} / \mathrm{cm} \pm$ 114.95, the EC value of the water samples was higher than that of the dry season (Table 6). The lowest EC value was observed in the water sample from
NO $\left(1.32 \times 10^{2} \mu \mathrm{S} / \mathrm{cm} \pm 0.58\right)$ while the highest value was recorded for the well water sample from $\mathrm{OB}\left(1.88 \times 10^{3} \mu \mathrm{S} / \mathrm{cm}\right.$ \pm 5.77). They were both significantly different $(\mathrm{P}<0.05)$ form the EC value of other well water samples.

\section{water}

Bacteriological quality of well

The dry season total and faecal coliform counts of the well water samples are shown on Table 7. All tested water samples had coliform bacteria. The highest total coliform count; $8.479 \times 10^{3}$ $\mathrm{cfu} / \mathrm{mL}$ and faecal coliform count; $2.29 \mathrm{x}$ $10^{2} \mathrm{cfu} / \mathrm{mL}$ in the dry season were observed in the well water sample from ISL which was located $28.90 \mathrm{~m}$ away from the household's sewage pit. The lowest count of total coliform in the dry season; $5.5 \mathrm{x} 10 \mathrm{cfu} / \mathrm{mL}$ was observed in 
the well water sample from SJ which was sited $22.60 \mathrm{~m}$ away from the sewage pit and was not significantly different from the coliform counts of water samples from AL (7.9 x $10 \mathrm{cfu} / \mathrm{mL})$, NO (7.5 x 10 $\mathrm{cfu} / \mathrm{mL}), \mathrm{OL}(7.1 \times 10 \mathrm{cfu} / \mathrm{mL})$ and $\mathrm{RB}$ $(7.6 \times 10 \mathrm{cfu} / \mathrm{mL})$ which were sited at $30.00 \mathrm{~m}, 34.29 \mathrm{~m}, 16.72 \mathrm{~m}$ and $16.20 \mathrm{~m}$ away from sewage pits respectively. The well water sample from SJ also had the lowest faecal coliform count for the dry season; $1.2 \times 10 \mathrm{cfu} / \mathrm{mL}$, although the count was not significantly different from those of AL $(1.8 \times 10 \mathrm{cfu} / \mathrm{mL})$, BSB $(1.3 \mathrm{x}$ $10 \mathrm{cfu} / \mathrm{mL}), \mathrm{FJ}(1.6 \times 10 \mathrm{cfu} / \mathrm{mL}), \mathrm{IJ}(2.6 \mathrm{x}$ $10 \mathrm{cfu} / \mathrm{mL})$, IS (1.9 x $10 \mathrm{cfu} / \mathrm{mL})$, NO (1.8 x $10 \mathrm{cfu} / \mathrm{mL}), \mathrm{OB}(1.8 \times 10 \mathrm{cfu} / \mathrm{mL}), \mathrm{OL}$
(1.6 x $10 \mathrm{cfu} / \mathrm{mL}), \mathrm{RB}(2.3 \times 10 \mathrm{cfu} / \mathrm{mL})$, and SH (1.8 x $10 \mathrm{cfu} / \mathrm{mL})$, sited $30.00 \mathrm{~m}$, $31.80 \mathrm{~m}, \quad 6.71 \mathrm{~m}, \quad 10.26 \mathrm{~m}, \quad 13.06 \mathrm{~m}$, $34.29 \mathrm{~m}, 6.23 \mathrm{~m}, 16.72 \mathrm{~m}, 16.20 \mathrm{~m}$ and $8.54 \mathrm{~m}$ away from sewage pits, respectively.

The total and faecal coliform counts of the well water samples in the rainy season are shown on Table 8 . It was observed that well water sample from SJ had the highest total and faecal coliform counts with $9.45 \times 10^{4} \mathrm{cfu} / \mathrm{mL}$ and $2.36 \times 10^{4} \mathrm{cfu} / \mathrm{mL}$, respectively. Well water sample from NO had the lowest total and faecal coliform counts with $1.2 \times 10 \mathrm{c} \mathrm{fu} / \mathrm{mL}$ and $1.0 \times 10 \mathrm{cfu} / \mathrm{mL}$, respectively.

Table 7. Coliform counts of well water in dry season.

\begin{tabular}{|c|c|c|c|c|}
\hline $\begin{array}{l}\text { Sites } \\
\text { well }\end{array}$ & $\begin{array}{l}\text { Total coliform } \\
\text { count }(\mathrm{cfu} / \mathrm{mL} \text { ) }\end{array}$ & $\begin{array}{l}\text { Faecal coliform } \\
\text { count }(\mathrm{cfu} / \mathrm{mL})\end{array}$ & $\begin{array}{l}\text { Distance of well to } \\
\text { sewage pit (m) }\end{array}$ & Depth of well (m) \\
\hline $\mathrm{AA}$ & $3.59 \times 10^{2 \mathrm{k}}$ & $5.2 \times 10 \mathrm{de}$ & 11.91 & 8.45 \\
\hline$\overline{\mathrm{AL}}$ & $7.9 \times 10^{a b c}$ & $1.8 \times 10^{a b}$ & 30.00 & 3.65 \\
\hline $\mathrm{AU}$ & $1.17 \times 10^{2} \mathrm{def}$ & $3.3 \times 10^{\mathrm{bcd}}$ & 16.33 & 5.93 \\
\hline BSB & $8.6 \times 10^{b c}$ & $1.3 \times 10^{\mathrm{a}}$ & 31.80 & 4.32 \\
\hline FJ & $1.04 \times 10^{2} \mathrm{cde}$ & $1.6 \times 10^{\mathrm{ab}}$ & 6.71 & 5.23 \\
\hline IG & $1.98 \times 10^{2} \mathrm{I}$ & $5.6 \times 10^{\mathrm{e}}$ & 22.70 & 3.78 \\
\hline IJ & $1.35 \times 10^{2} \mathrm{efg}$ & $2.6 \times 10^{a b c}$ & 10.26 & 2.96 \\
\hline IR & $1.47 \times 10^{2} \mathrm{fg}$ & $4.4 \times 10^{\text {cde }}$ & 5.38 & 2.97 \\
\hline IS & $8.6 \times 10^{b c}$ & $1.9 \times 10^{a b}$ & 13.06 & 5.15 \\
\hline ISL & $8.479 \times 10^{31}$ & $2.29 \times 10^{2} \mathrm{~g}$ & 28.90 & 1.58 \\
\hline NO & $7.5 \times 10 \mathrm{abc}$ & $1.8 \times 10^{\mathrm{ab}}$ & 34.29 & 12.50 \\
\hline OB & $7.8 \times 10^{a b c}$ & $1.8 \times 10^{\mathrm{ab}}$ & 6.23 & 8.09 \\
\hline $\mathrm{OE}$ & $9.8 \times 10^{b c d}$ & $5.0 \times 10 \mathrm{de}$ & 20.40 & 6.98 \\
\hline 00 & $1.64 \times 10^{2 \mathrm{gh}}$ & $6.0 \times 10^{\mathrm{e}}$ & 7.50 & 3.59 \\
\hline OL & $7.1 \times 10$ ab & $1.6 \times 10^{\mathrm{ab}}$ & 16.72 & 7.80 \\
\hline OS & $1.89 \times 10^{2 \mathrm{hi}}$ & $5.3 \times 10^{\mathrm{e}}$ & 13.51 & 8.90 \\
\hline $\mathrm{RB}$ & $7.6 \times 10 \mathrm{abc}$ & $2.3 \times 10^{a b}$ & 16.20 & 10.76 \\
\hline SH & $8.6 \times 10^{b c}$ & $1.8 \times 10^{\mathrm{ab}}$ & 8.54 & 7.06 \\
\hline SJ & $5.5 \times 10^{a}$ & $1.2 \times 10^{\mathrm{a}}$ & 22.60 & 4.95 \\
\hline $\mathrm{TI}$ & $2.63 \times 10^{2 j}$ & $9.3 \times 10^{\mathrm{f}}$ & 29.40 & 4.62 \\
\hline
\end{tabular}

*Values with the same letter along the same column are not significantly different at $\mathrm{P}<0.05$ using Tukey's post-hoc test. 
Table 8. Coliform counts of well water in rainy season.

\begin{tabular}{|c|c|c|c|c|}
\hline $\begin{array}{l}\text { Sites } \\
\text { well }\end{array}$ & $\begin{array}{l}\text { Total coliform } \\
\text { count }(\mathrm{cfu} / \mathrm{mL} \text { ) }\end{array}$ & $\begin{array}{l}\text { Faecal coliform } \\
\text { count }(\mathrm{cfu} / \mathrm{mL})\end{array}$ & $\begin{array}{l}\text { Distance of well to } \\
\text { sewage pit (m) }\end{array}$ & Depth of well (m) \\
\hline $\mathrm{AA}$ & $1.71 \times 10^{4} \mathrm{I}$ & $1.08 \times 10^{4 \mathrm{~h}}$ & 11.91 & 8.45 \\
\hline$\overline{\mathrm{AL}}$ & $7.281 \times 10^{3 \mathrm{~h}}$ & $2.372 \times 10^{3 \mathrm{f}}$ & 30.00 & 3.65 \\
\hline $\mathrm{AU}$ & $6.03 \times 10^{2 \mathrm{c}}$ & $1.53 \times 10^{2 \mathrm{c}}$ & 16.33 & 5.93 \\
\hline BSB & $1.505 \times 10^{3} \mathrm{~g}$ & $2.66 \times 10^{2 \mathrm{~d}}$ & 31.80 & 4.32 \\
\hline FJ & $9.36 \times 10^{2} \mathrm{e}$ & $1.41 \times 10^{2 \mathrm{c}}$ & 6.71 & 5.23 \\
\hline IG & $1.57 \times 10^{2 b}$ & $6.0 \times 10^{\mathrm{b}}$ & 22.70 & 3.78 \\
\hline IJ & $3.73 \times 10^{4 \mathrm{k}}$ & $5.701 \times 10^{3} \mathrm{~g}$ & 10.26 & 2.96 \\
\hline IR & $9.00 \times 10^{4 \mathrm{~m}}$ & $1.37 \times 10^{4 \mathrm{i}}$ & 5.38 & 2.97 \\
\hline IS & $1.68 \times 10^{2 \mathrm{~b}}$ & $4.2 \times 10^{a b}$ & 13.06 & 5.15 \\
\hline ISL & $5.90 \times 10^{2 c}$ & $1.48 \times 10^{2 \mathrm{c}}$ & 28.9 & 1.58 \\
\hline NO & $1.20 \times 10^{\mathrm{a}}$ & $1.00 \times 10^{\mathrm{a}}$ & 34.29 & 12.50 \\
\hline OB & $7.05 \times 10^{2 \mathrm{~cd}}$ & $1.62 \times 10^{2 \mathrm{c}}$ & 6.23 & 8.09 \\
\hline $\mathrm{OE}$ & $2.61 \times 10^{4 j}$ & $6.20 \times 10^{2} \mathrm{e}$ & 20.4 & 6.98 \\
\hline 00 & $1.60 \times 10^{2 \mathrm{~b}}$ & $1.60 \times 10^{2 \mathrm{c}}$ & 7.50 & 3.59 \\
\hline $\mathrm{OL}$ & $5.94 \times 10^{41}$ & $1.73 \times 10^{2 \mathrm{c}}$ & 16.72 & 7.80 \\
\hline OS & $1.153 \times 10^{3 \mathrm{f}}$ & $2.88 \times 10^{2 \mathrm{~d}}$ & 13.51 & 8.90 \\
\hline $\mathrm{RB}$ & $4.60 \times 10 \mathrm{ab}$ & $0.30 \times 10^{\mathrm{a}}$ & 16.20 & 10.76 \\
\hline SH & $7.76 \times 10^{2 \mathrm{~d}}$ & $3.00 \times 10^{a b}$ & 8.54 & 7.06 \\
\hline SJ & $9.45 \times 10^{4 n}$ & $2.36 \times 10^{4 j}$ & 22.60 & 4.95 \\
\hline $\mathrm{TI}$ & $1.61 \times 10^{2 \mathrm{~b}}$ & $4.10 \times 10^{a b}$ & 29.40 & 4.62 \\
\hline
\end{tabular}

*Values with the same letter along the same column are not significantly different at $\mathrm{P}<0.05$ using Tukey's post-hoc test.

\section{Comparison of coliform counts of well based on well characteristics}

The geometric mean of the total and faecal coliform counts of the well water samples in the dry and rainy seasons based on the different properties of the wells were presented on Table 9 ( for dry season ) and Table 10 (for rainy season). The comparison of the total coliform counts and faecal coliform counts of the well water samples based on their orientation to sewage pit showed that water samples from wells sited down-gradient in orientation to sewage pit had a higher mean total and faecal coliform count than the wells sited up-gradient in orientation to sewage pit in both dry and rainy seasons. Ringed wells; which made up $90 \%$ of the observed wells, had higher mean total coliform and faecal coliform counts than the unringed wells $110 \%$ of observed wells) in both seasons. Likewise in the covered wells (which also totalled 90\% of the studied wells), mean total coliform and faecal coliform counts were higher than those of the uncovered wells in both dry and rainy seasons.

Wells with uncemented well area had higher mean total coliform and faecal coliform counts than wells with cemented well area in both dry and rainy seasons. The assessment of the coliform counts of wells based on the method of water withdrawal from the wells revealed that the pumped wells had higher mean total coliform count and faecal coliform count in both dry and rainy season than wells from which water is fetched and pumped and those from which fetching is the sole method of water withdrawal. Wells located in sandy soil area had a higher mean total coliform and faecal coliform count than 
those sited in the clay soil area in the dry season. Contrariwise, in the rainy season, water samples from wells sited in clay soil area had higher total and faecal coliform counts than samples from wells sited in sandy soil areas.

Table 9. Comparison of means of coliform counts and physicochemical properties of wells based on well properties in dry season.

\begin{tabular}{|c|c|c|c|c|c|c|c|c|c|}
\hline $\begin{array}{l}\text { Well } \\
\text { Characteritics }\end{array}$ & $\begin{array}{l}\text { Number } \\
\text { of wells }\end{array}$ & $\begin{array}{c}\text { Mean } \\
\text { distance } \\
\text { from } \\
\text { sewage } \\
\text { pit (m) }\end{array}$ & $\begin{array}{l}\text { Mean } \\
\text { depth of } \\
\text { wells } \\
\text { (m) }\end{array}$ & $\begin{array}{c}\text { Mean } \\
\text { faecal } \\
\text { coliform } \\
\text { count } \\
(\mathrm{cfu} / \mathrm{mL})\end{array}$ & $\begin{array}{c}\text { Mean } \\
\text { Total } \\
\text { coliform } \\
\text { count } \\
(\mathrm{cfu} / \mathrm{mL})\end{array}$ & $\begin{array}{c}\text { Mean } \\
\text { Temperature } \\
\left({ }^{\circ} \mathrm{C}\right)\end{array}$ & $\begin{array}{c}\text { Mean } \\
\text { pH }\end{array}$ & $\begin{array}{c}\text { Mean } \\
\text { Dissolved } \\
\text { Oxygen } \\
\left(\mathrm{DO}_{2}\right) \\
(\mathrm{mg} / \mathrm{L})\end{array}$ & $\begin{array}{c}\text { Mean } \\
\text { Electrical } \\
\text { Conductivity } \\
(\mu \mathrm{S} / \mathrm{cm})\end{array}$ \\
\hline $\begin{array}{l}\text { Down gradient to } \\
\text { sewage }\end{array}$ & 11 & 14 & 5 & $35^{*}$ & $177^{*}$ & $28.0^{*}$ & 6.2 & $1.4^{*}$ & $360^{*}$ \\
\hline $\begin{array}{l}\text { Up gradient to } \\
\text { sewage }\end{array}$ & 9 & $16^{*}$ & $7^{*}$ & 26 & 107 & 27.8 & 6.2 & 1.0 & 231 \\
\hline Ringed & 18 & $16^{*}$ & 5 & 31 & $144^{*}$ & 27.9 & $6.3^{*}$ & 1.2 & 284 \\
\hline Unringed & 2 & 9 & $9^{*}$ & 31 & 121 & $28.2^{*}$ & 5.8 & $2.0^{*}$ & $414^{*}$ \\
\hline Covered & 18 & 15 & 5 & $32^{*}$ & $147^{*}$ & $27.9^{*}$ & $6.2^{*}$ & 1.2 & $318^{*}$ \\
\hline Uncovered & 2 & $19^{*}$ & $6^{*}$ & 22 & 101 & 27.8 & 5.9 & $2.1^{*}$ & 148 \\
\hline Cemented & 11 & $16^{*}$ & $6^{*}$ & 28 & 110 & 27.6 & $6.3^{*}$ & 1.0 & 271 \\
\hline Uncemented & 9 & 14 & 4 & $35^{*}$ & $192^{*}$ & $28.2^{*}$ & 6.1 & $1.6^{*}$ & $328^{*}$ \\
\hline Fetched & 14 & 15 & 5 & 32 & 155 & $28.1^{*}$ & $6.3^{*}$ & 1.2 & $358^{*}$ \\
\hline Pumped & 2 & $16^{*}$ & $8^{*}$ & $50^{*}$ & $188^{*}$ & 27.7 & 6.1 & 0.4 & 176 \\
\hline $\begin{array}{l}\text { Fetched } \\
\text { Pumped }\end{array}$ & 4 & $16^{*}$ & 7 & 21 & 90 & 27.4 & 6.0 & $2.2^{*}$ & 194 \\
\hline Sandy soil & 13 & 15 & 5 & $32^{*}$ & $162^{*}$ & $28.2^{*}$ & 6.2 & $1.5^{*}$ & $342^{*}$ \\
\hline Clay soil & 7 & $16^{*}$ & $7^{*}$ & 29 & 110 & 27.4 & $6.3^{*}$ & 0.8 & 224 \\
\hline
\end{tabular}

*Higher mean values.

Table 10. Comparison of means of coliform counts and physicochemical properties of wells based on well properties in wet season.

\begin{tabular}{|c|c|c|c|c|c|c|c|c|c|}
\hline $\begin{array}{l}\text { Well } \\
\text { Characteritics }\end{array}$ & $\begin{array}{l}\text { Number } \\
\text { of wells }\end{array}$ & $\begin{array}{c}\text { Mean } \\
\text { distance } \\
\text { from } \\
\text { sewage } \\
\text { pit (m) }\end{array}$ & $\begin{array}{l}\text { Mean } \\
\text { depth of } \\
\text { wells } \\
\text { (m) }\end{array}$ & $\begin{array}{c}\text { Mean } \\
\text { faecal } \\
\text { coliform } \\
\text { count } \\
(\mathrm{cfu} / \mathrm{mL})\end{array}$ & $\begin{array}{c}\text { Mean } \\
\text { Total } \\
\text { coliform } \\
\text { count } \\
(\mathrm{cfu} / \mathrm{mL})\end{array}$ & $\begin{array}{c}\text { Mean } \\
\text { Temperature } \\
\left({ }^{\circ} \mathrm{C}\right)\end{array}$ & $\begin{array}{c}\text { Mean } \\
\mathrm{pH}\end{array}$ & $\begin{array}{c}\text { Mean } \\
\text { Dissolved } \\
\text { Oxygen } \\
\left(\mathrm{DO}_{2}\right) \\
(\mathrm{mg} / \mathrm{L})\end{array}$ & $\begin{array}{c}\text { Mean } \\
\text { Electrical } \\
\text { Conductivity } \\
(\mu \mathrm{S} / \mathrm{cm})\end{array}$ \\
\hline $\begin{array}{l}\text { Down gradient to } \\
\text { sewage pit }\end{array}$ & 11 & 14 & 5 & $1,217^{*}$ & $5,423^{*}$ & 28.4 & 5.8 & $3.4^{*}$ & $595^{*}$ \\
\hline $\begin{array}{l}\text { Up gradient to } \\
\text { sewage pit }\end{array}$ & 9 & $16^{*}$ & $7^{*}$ & 41 & 340 & $28.5^{*}$ & $6.0^{*}$ & 3.2 & 350 \\
\hline Ringed & 18 & $16^{*}$ & 5 & $272^{*}$ & $1,658^{*}$ & $28.5^{*}$ & $6.0^{*}$ & 3.2 & 438 \\
\hline Unringed & 2 & 9 & $9^{*}$ & 216 & 902 & 28.4 & 5.0 & $4.1^{*}$ & $859 *$ \\
\hline Covered & 18 & 15 & 5 & $269^{*}$ & $1,713^{*}$ & $28.5^{*}$ & $5.9^{*}$ & $3.4^{*}$ & $393^{*}$ \\
\hline Uncovered & 2 & $19^{*}$ & $6^{*}$ & 239 & 669 & 28.1 & 5.7 & 2.5 & 229 \\
\hline Cemented & 11 & $16^{*}$ & $6^{*}$ & 192 & 1,543 & 28.4 & $6.0^{*}$ & 3.2 & 387 \\
\hline Uncemented & 9 & 14 & 4 & $395^{*}$ & $1,580^{*}$ & $28.5^{*}$ & 5.7 & $3.4^{*}$ & $592^{*}$ \\
\hline Fetched & 14 & 15 & 5 & 336 & 2,007 & 28.4 & $5.9^{*}$ & 3.2 & $583^{*}$ \\
\hline Pumped & 2 & $16^{*}$ & $8^{*}$ & $2,588^{*}$ & $21,108^{*}$ & $29.1^{*}$ & 5.7 & 3.1 & 253 \\
\hline $\begin{array}{l}\text { Fetched } \\
\text { Pumped }\end{array}$ & 4 & $16^{*}$ & 7 & 37 & 175 & 28.1 & $5.9^{*}$ & $3.8^{*}$ & 296 \\
\hline Sandy soil & 13 & 15 & 5 & 185 & 1,144 & $28.6^{*}$ & 5.8 & 3.2 & $558^{*}$ \\
\hline Clay soil & 7 & $16^{*}$ & $7^{*}$ & $518^{*}$ & $2,773^{*}$ & 28.2 & $6.1^{*}$ & $3.4^{*}$ & 243 \\
\hline
\end{tabular}

*Higher mean values.

\section{Correlation between coliform counts and distances of wells to sewage pits in different seasons}

Dry season correlation between total coliform counts and the distances of wells to sewage pits was positive $(\mathrm{r}=$ $0.279, \mathrm{~N}=20, \mathrm{P}=0.12$ ). Likewise, the dry season correlation of faecal coliform counts to the distances of wells to sewage pits was also positive $(r=0.265$, 
$\mathrm{N}=20, \mathrm{P}=0.13$ ). However, none of these correlations were significant at $\mathrm{P}<0.05$. Contrarily, the rainy season correlation of both total coliform $(\mathrm{r}=-0.167, \mathrm{~N}=20$, $\mathrm{P}=0.04)$ and faecal coliform $(\mathrm{r}=-0.112$, $\mathrm{N}=20, \mathrm{P}=0.04$ ) to the distances between wells and sewage pits was negative and significant at $\mathrm{P}<0.05$.

\section{Correlation between coliform counts and depths of wells in different seasons}

The correlation of well depth to the total coliform count $(\mathrm{r}=0.399, \mathrm{~N}=$ $20, P=0.23$ ) and faecal coliform counts $(\mathrm{r}=0.435, \mathrm{~N}=20, \mathrm{P}=0.21)$ in dry season were positive and not significant at $\mathrm{P}<0.05$. The correlation of these parameters for the rainy season; Total coliform ( $\mathrm{r}=-0.173, \mathrm{~N}=20, \mathrm{P}=0.04$ ), faecal coliform $(\mathrm{r}=-0.192, \mathrm{~N}=20, \mathrm{P}=$ 0.03 ) were however negative and significant at $\mathrm{P}<0.05$ (Table 9).

Difference in concentration of well water parameters between dry and rainy seasons

A paired sample T-test to check for differences in concentrations of well water parameters between dry and rainy seasons revealed that the temperature $(\mathrm{t}(20)=-3.907, \mathrm{P}=0.00), \mathrm{pH}(\mathrm{t}(20)=$ 5.008, $\mathrm{P}=0.00), \mathrm{EC}(\mathrm{t}(20)=-4.003, \mathrm{P}=$ $0.00), \mathrm{DO}_{2}(\mathrm{t}(20)=-7.396, \mathrm{P}=0.00)$, total coliform counts $(\mathrm{t}(20)=-2.408, \mathrm{P}=0.03)$ and faecal coliform counts $(\mathrm{t}$ (20) = -2.177, $P=0.05$ ) were significantly different $(P \leq 0.05)$ between the rainy and dry season.

\section{Use of well water in households
Results pooled from the} administered questionnaires showed that 35\% (70) of the respondents drink the water from their wells, $80 \%$ (160) use the water to cook while 55\% (110) use the water for washing.

\section{Treatment methods of well water in different households \\ Different methods of well} treatment were reported; $25 \%$ (5) of the wells sampled are treated with chlorine, other methods (which were undisclosed) were used in the treatment of 5\% (1) of the wells, while the remaining $70 \%$ (14) of the wells were reported not to have been treated. The treatment period of the wells also differed with $10 \%$ (2) of the wells receiving treatment every 6 months while another $20 \%$ (4) receive treatment annually.

\section{Diseases suffered in households dependent on well water}

Results showed the percentage of respondents that have suffered from water borne disease in different well water dependent households. 5\% (10) of the respondents that drink from the well reported to have suffered from cholera while another 15\% (30) reported to have suffered from typhoid.

\section{Discussion}

Findings from this study show that water from wells in Akure contain high coliform bacteria. Groundwater is generally believed to be relatively free of microorganisms and thus fit for consumption (Akoachere et al., 2013). However, increase in human population in urban areas has exerted enormous pressure on the provision of safe drinking water. Consequently, the provision of high quality water as well as protecting and conserving this scarce water resources is therefore one of the challenges facing national and regional governments (Jamieson et al., 2004). Well water; which currently serves as a cheap alternative source of potable water is as well under the threat of being polluted, most especially by faecal contaminants from sewage pits. 
This study revealed that at an average distance of $17.6 \mathrm{~m}$ from the sewage pits, the mean total coliform counts in water samples for the dry and rainy season were $5.47 \times 10^{2} \mathrm{cfu} / \mathrm{mL}$ and $1.69 \times 10^{4} \mathrm{cfu} / \mathrm{mL}$, while the average faecal coliform counts were $4.30 \times 10$ $\mathrm{cfu} / \mathrm{mL}$ and $2.93 \times 10^{3} \mathrm{cfu} / \mathrm{mL}$ for the dry and rainy season respectively. A loose overview of the distance between sewage pits and wells show that wells closer to this source of contamination have higher coliform counts than wells sited farther away. These coliform counts are higher than the WHO standard which stated that coliforms or faecal coliform must not be detectable in any $100 \mathrm{~mL}$ of drinking water (WHO, 2008).

This situation is not peculiar to Akure alone as it appears to be the trend in most urban cities where the high dependence on well water has encouraged the siting of wells and sewage pits in same compound. Similar investigations by Arnade (2005), Akoachere et al. (2013), Aladejana and Talabi (2013), Olatunji and Oladepo (2013), Adetunji and Odetokun (2011), Akinbile and Yussof (2011), NguendoTongsi (2011), Olobaniyi et al. (2007) and Olabisi et al. (2007) have all attributed the presence of coliforms, faecal coliforms and pathogens such as Esherichia coli, Streptococcus sp., Pseudomonas sp., Salmonella sp. and Vibrio $s p$. in large numbers to the proximity of household drinking water supply to septic tanks and pit latrines which serve as sources from which these species emanate, through seepages and infiltration. Adekunle (2008), Fasunwon et al. (2008), Oparaocha et al. (2008) and Adelekan, (2010) have also reported higher heterotrophic bacterial counts. Ifabiyi (2008) and Akinbile and Yusoff (2011), recorded high values for Total coliform counts in various groundwater wells while some others noted high Total aerobic counts (Shittu et al., 2008; Akahaan et al., 2010; Orebiyi et al., 2010; Adejuwon and Mbuk, 2011; Adejuwon and Adeniyi, 2011). Eiswirth and Hotzl
(1997) reported that the impact of leaking sewers on urban groundwater produce a potential risk for soil and groundwater contamination. As such, high counts of indicator bacteria suggest heavy pollution of water with faecal matter (Olabisi et al., 2007; Adetunji and Odetokun, 2011) and therefore require urgent public health attention. The presence of these indicator organisms in drinking water sources may provide an indication of water-borne problems (Mackenzie et al., 1995) and is a direct threat to human health (Khalid et al., 2011a; Khalid et al., 2011b; Farzana et al., 2011). With 5\% (10) and another $15 \%$ (30) of the respondents claiming to have suffered from cholera and typhoid respectively, the reported uses of well water which included drinking (35\%), cooking (80\%) and washing (55\%) could be assumed to be factors that predisposed the people to these waterborne diseases as any water source used for drinking or cleaning purposes should not contain any organism of faecal origin (Akeredolu, 1991).

Asides the proximity of wells to sewage pits (Ibe and Okpelenye, 2005), various other factors such as well depth, prevailing weather condition, orientation of wells to sewage pit, well properties and nature of well-site could have facilitated the migration and entrance of faecal contaminants from sewage pits into well water. The mean faecal coliform count of the wells was generally higher in the rainy season $(4.3 \times 10 \mathrm{cfu} / \mathrm{mL})$ than in the dry season $\left(2.93 \times 10^{3} \mathrm{cfu} / \mathrm{mL}\right)$. This is attributed to the fact that excess rainwater that infiltrates and percolates the soil will help transport more pathogens in the soil (Eiswirth and Hotzl, 1997). The underground water table is most probably contaminated via large numbers of sewage pits and similar conveniences. Downward movement of contaminant from the shallow conveniences into deeper water tables may explain the well depth indicator bacteria correlation. In situations where the well is sited up-gradient in 
orientation to the sewage pit, water draining down-gradient will likely convey pathogens from the sewage pit down into the well water. This might be the cause of the higher mean faecal coliform count (dry season: $3.5 \times 10$ $\mathrm{cfu} / \mathrm{mL}$; rainy season: $1.22 \times 10^{3} \mathrm{cfu} / \mathrm{mL}$ ) observed in wells down-gradient in orientation to the sewage pit than those up-gradient in orientation to the sewage pit (dry season: $2.6 \times 10 \mathrm{cfu} / \mathrm{mL}$; rainy season: $4.1 \times 10 \mathrm{cfu} / \mathrm{mL}$ ).

Although $80 \%$ (18) of the wells studied were ringed, and the remaining $20 \%$ (2) were not ringed, their mean faecal coliform counts in the dry season were the same; $3.1 \times 10 \mathrm{cfu} / \mathrm{mL}$. The case was however different in the rainy season as the ringed wells had a mean faecal coliform count of $2.72 \times 10^{2}$ $\mathrm{cfu} / \mathrm{mL}$ which was higher than that of the unringed wells; $2.16 \times 10^{2} \mathrm{cfu} / \mathrm{mL}$. Nonetheless, considering the ratio of the ringed wells to unringed wells, it can be deduced that the unringed wells had more influx of coliform than the ringed wells in the rainy season. Also, with $80 \%$ (18) of the wells covered and 20\% (2) uncovered, the mean faecal coliform count followed a similar pattern as that of the ringed and unringed wells. The covered wells had mean faecal coliform counts of $3.2 \times 10 \mathrm{cfu} / \mathrm{mL}$ in the dry season and $2.69 \times 10^{2} \mathrm{cfu} / \mathrm{mL}$ in the rainy season as against lower mean faecal coliform counts of $2.2 \times 10 \mathrm{cfu} / \mathrm{mL}$ in the dry season and $2.39 \times 10^{2} \mathrm{cfu} / \mathrm{mL}$ in the rainy season for the uncovered wells. The ratio of the covered wells $(80 \%)$ to uncovered wells $(20 \%)$ also stands out as the reason for these observations because if the ratio were to be equal, the uncovered wells could have been present with more coliform bacteria.

Wells with uncemented floor area were observed to have mean faecal coliform counts of $3.5 \times 10 \mathrm{cfu} / \mathrm{mL}$ in the dry season and $3.95 \times 10^{2} \mathrm{cfu} / \mathrm{mL}$ in the rainy seasons which were higher than mean faecal coliform counts of the wells with cemented floor area in the rainy $\left(2.8 \times 10 \mathrm{cfu} / \mathrm{mL}\right.$ and dry $\left(1.92 \times 10^{2}\right.$ $\mathrm{cfu} / \mathrm{mL}$ ) seasons. The lower mean faecal coliform counts observed in the wells with cemented floor area could be due to the presence of the concrete flooring which acts as a barrier to direct percolation of water which otherwise would have travelled freely into soil and well water without obstruction in the case of wells with uncemented floor area.

Water withdrawal method could have an impact on the presence of coliforms in the well water samples. Wells from which water is pumped solely (10\%) had mean faecal coliform counts of $5.0 \times 10 \mathrm{cfu} / \mathrm{mL}$ in the dry season and $2.59 \times 10^{3} \mathrm{cfu} / \mathrm{mL}$ in the rainy season. This was higher than the mean faecal coliform count of wells from which water is fetched and pumped (65\%) and those from which fetching is the sole method of water withdrawal (25\%). The mean faecal coliform counts of wells from which water is both fetched and pumped was $2.1 \times 10 \mathrm{cfu} / \mathrm{mL}$ and $3.7 \times 10 \mathrm{cfu} / \mathrm{mL}$ in the dry and rainy season respectively, while that of the wells from which fetching is the sole method of water withdrawal was $3.2 \times 10 \mathrm{cfu} / \mathrm{mL}$ and $3.36 \times 10^{2} \mathrm{cfu} / \mathrm{mL}$ in the dry and rainy season respectively. This observation might be due to the imbalance in the ratio of the wells to one another using the water withdrawal method as a factor. On the other hand, wells from which water is fetched undergoes a constant agitation through the dropping and scooping of fetching buckets. These may likely disturb the activities of microbes and promote the influx of oxygen into water, as such preventing an anaerobic condition that may favour the explosion of the microbes. Wells from which water is pumped however presents a more stable environment which may tend to be conducive for the survival of coliform bacteria.

The nature of the soil in the well area will have an effect on the rate of water flow and water holding capacity of the soil. Consequently, wells located in sandy soil area had a higher mean faecal 
coliform $(3.2 \times 10 \mathrm{cfu} / \mathrm{mL})$ than those sited in the clay soil area $(2.9 \times 10$ $\mathrm{cfu} / \mathrm{mL}$ ) in the dry season. This might be as a result of the porosity of the sandy soil which allows for easy movement of water molecules (Akoachere et al., 2013) as against the compact nature of the clay soil that hinders the free flow of water. Contrariwise, in the rainy season, water samples from wells sited in clay soil area had higher mean faecal coliform count $\left(5.18 \times 10^{2} \mathrm{cfu} / \mathrm{mL}\right)$ than samples from wells sited in sandy soil areas $\left(1.85 \times 10^{2}\right.$ $\mathrm{cfu} / \mathrm{mL}$. This might also be due to the capability of clay soil to hold more water than the sandy soil. As such, contaminants may flow through sandy soil faster while they are retained for a longer period in the clay soil areas.

Generally, the average distance of the wells from the sewage pits irrespective of the observed characteristics is considered the most influential predisposing factor to contamination. In view of the average distances of the wells based on characteristics such as down-gradient in orientation to sewage pit $(14 \mathrm{~m})$, upgradient in orientation to sewage pit $(16 \mathrm{~m})$, ringed $(16 \mathrm{~m})$, unringed $(9 \mathrm{~m})$, covered $(15 \mathrm{~m})$, uncovered $(19 \mathrm{~m})$, cemented floor area $(16 \mathrm{~m})$, uncemented floor area $(14 \mathrm{~m})$, fetched $(15 \mathrm{~m})$, pumped $(16 \mathrm{~m})$, sandy soil area $(15 \mathrm{~m})$ and clay soil area $(16 \mathrm{~m})$, they all fail to conform with the specified standard distances (WHO, 1996; Ball et al., 2007; USEPA, 2009).

The correlation between coliform counts of water samples and the distances of the wells to sewage pits showed that the dry season correlation between faecal coliform counts and the distances of wells to sewage pits was positive. This agrees with the result of Asheesh (1994) who did not find any association between the bacteriological quality of dug-well and distance to the nearest pit latrines probably due to the season of the year the experiment was conducted. Contrarily, the rainy season correlation of the faecal coliform and to the distances between wells and sewage pits was negative. This agrees with the observations of Ibe and Okpelenye (2005), Adetunji and Odetokun (2011), Muruka et al. (2012), and Akoachere et al. (2013) that reported a negative correlation between well distance and bacterial counts of well water samples. Thus depicting the impact of the closeness of the sewage pits on the contamination of the wells. The low negative correlation is an indication that there are other factors (such as the gradient and well protection measures) that contribute to well water contamination.

The faecal coliform counts correlation to well depth in dry season was positive and not significant $(\mathrm{P}<0.05)$. The correlation of these parameters for the rainy season was however negative and significant $(\mathrm{P}<0.05)$. Guevart et al. (2006) and Akoachere et al. (2013) argued that deep wells are less prone to contamination. As such, the observed positive correlation might be due to the drop in groundwater level in the dry season whereby only a small amount of water will be available to amass the microbes. The increase in water level in the rainy season coupled with the inflow of water from the surrounding soil will lead to a bloom (Olabisi et al., 2007). Thus, more microbes will be present to subsist on the surface of the water.

The significant drop in $\mathrm{pH}$ and observed increase in the physicchemical parameters; temperature, $\mathrm{EC}, \mathrm{DO}_{2}$ and coliform counts in the rainy season suggests there is an influx of microbes and minerals likely transported by the water infiltrating the soil into the groundwater. As these increase tend to be more pronounced in the vulnerable unprotected wells (down-gradient, unringed, uncemented floor area, sandy soil area); it is evident that there is a flow of materials (part of which may likely be contaminants from the sewage pits) into the wells. 


\section{Conclusion}

Findings from the research revealed that all wells sampled have high coliform counts above the recommended level for drinking water, thereby necessitating the need for urgent public health intervention. Overcrowding, settlement pattern and land use practices in study sites leaves inhabitants with limited distance between wells and sanitary structures as such; wells are often located too close to sanitation systems in households without taking water quality into cognizance. Asides the distance between wells and sewage pit and topography, other factors such as seasonal variation, inadequate hygiene and sanitation, well disinfection and well characteristics play significant role in the level of well water contamination.

Attendant regular and sustained communal disinfection programmes in study sites should be embarked on. Alongside, there is need to increase awareness of the community towards the dangers associated with the use of contaminated water; the danger in constructing septic tanks near water sources and vice versa and treatment of water by boiling and filtering before use for drinking, cooking and washing. In addition to this, there should be restrictions on the free ranging domestic animals and other domestic solid wastes which are dumped around the house; which could be possible sources of bacteria pollution of the shallow wells. Relevant Government parastatals should pass laws concerning well construction. Such regulations should ensure wells are sited at least 30 metres away from sewage pit and are sited uphill in orientation to sanitation systems. Preference should be given to water protection through well monitoring and routine analysis of well water samples over the sporadic campaigns against outbreak waterborne infections. Change assessment studies should also be conducted to evaluate the trend of the groundwater pollution over time as waterborne diseases could continue to be a health problem in study sites if appropriate measures are not taken to improve on water quality.

\section{Conflict of interest}

The authors declare that there are no conflicts of interest.

\section{References}

Abdulsalam, A.; Zubairu, S. M. Sanitary condition of some hand dug wells in Zaria City, Northern Nigeria. IOSR Journal of Environmental Science, Toxicology And Food Technology, v. 2, p. 1-3, 2013.

Adejuwon, J. O.; Mbuk, C. J. Biological and physiochemical properties of shallow wells in Ikorodu Town, Lagos, Nigeria. Journal of Geology and Mining Research, v. 3, p. 161168, 2011.

Adejuwon, J. O.; Adeniyi, D. O. Pollution effect of pit latrines on shallow wells at IsaleIgbehin Community, Abeokuta, Nigeria. Journal of Geology and Mining Research, v. 3, p. 211-218, 2011.

Adekunle, A. S. Impacts of industrial effluent on quality of well water within Asa Dam Industrial Estate, Ilorin, Nigeria. Nature and Science, v. 6, p. 1-5, 2008.

Adelekan, B. A. Water quality of domestic wells in typical African communities: Case studies from Nigeria. International Journal of Water Resources and Environmental Engineering, v. 2, p. 137-147, 2010.

Adetunji, V. O.; Odetokun, I. A. Groundwater contamination in Agbowo Community, Ibadan Nigeria: Impact of septic tanks distances to wells. Malaysian Journal of Microbiology, v. 7, p. 159-166, 2011.

Akaahan, T. J.; Oluma, H. O. A.; Sha'Ato, R. Physico-chemical and bacteriological quality of water from shallow wells in two rural communities in Benue State, Nigeria. Pakistan Journal of Analytical and Environmental Chemistry, v. 11, p. 73-78, 2010.

Akeredolu, F. A. Setting water quality-water quality standards for Nigeria. Proceedings of First National Conference on Water Quality Monitoring and Status in Nigeria, Kaduna, p. 216-224, 1991. 
Akinbile, C. 0.; Yussof, M. S. Environmental impact of leachate pollution on groundwater supplies in Akure, Nigeria. International Journal of Environmental Science and Development, v. 2, p. 81-86, 2011.

Akoachere, J. T. K.; Omam, L.; Massalla, T. N. Assessment of the relationship between bacteriological quality of dug-wells, hygiene behaviour and well characteristics in two cholera endemic localities in Douala, Cameroon. Bio-Medical Central Public Health, v. 13, p. 692, 2013.

Aladejana, J. A.; Talabi, A. O. Assessment of groundwater quality in Abeokuta Southwestern, Nigeria: Research inventy. International Journal of Engineering and Science, v. 2, p. 21-31, 2013.

APHA - American Public Health Association. Standard methods for the examination of water and wastewater. 20. ed. Washington, D.C.: APHA, AWWWA, WEF, 1998.

Aribigbola, A.; Omosulu, S. B. Water supply situation in Owo, Ondo State: Implication for sustainable city development in Nigeria. European Journal of Business and Social Sciences, v. 1, p. 25-34, 2012.

Arnade, J. L. Seasonal correlation of well contamination and septic tank distance. Groundwater, v. 6, p. 920-923, 2005.

Asheesh, A. A longitudinal study of relationship between water quality, hygiene behavior and childhood diarrhoea in Langas, Eldoret. Eldoret: Moi University Community-Based Education Service Programme (COBES) Publication, 1994.

Ball, D.; Cantrell, B.; Fitzsimons, V.; Moran, S.; Wright, G.; Briody, P.; Cullen, K. In: Wright, G. (Ed.). Guidelines for drilling wells for private water supplies. Ireland: Institute of Geologists of Ireland, 2007.

Bayode, S.; Olorunfemi, M. O.; Ojo, J. S. Assessment of impact of some waste dumpsites on the groundwater quality in parts of Akure Metropolis, Southwestern Nigeria. The Pacific Journal of Science and Technology, v. 13, p. 2-6, 2012.

Birmingham, M. E.; Lea, L. A.; Ndayiminje, N.; Nkurikiye, S.; Hersh, B. S.; Wells, J. G.; Ijeming, M. S. Epidemic cholera in Burundi, patterns of transmission in the Gadat Rift Valley Lake Region. Lancet, v. 349, p. 981-983, 1997.

Blackburn, B. G.; Craun. G. F.; Yoder, J. S.; Hill, V.; Calderon, R. L.; Chen, N.; Lee, S. H.; Levy,
D. A.; Beach, M. J. Surveillance for waterborne-disease outbreaks associated with drinking water, United States, 20012002. MMWR CDC Surveillance Summary, v. 53, p. 23, 2004.

Burubai, W.; Akor, A. J.; Lilly, M. T.; Ayawari, D. T. An evaluation of septic tank performance in Bayelsa State, Nigeria. Agricultural Engineering International: The CIGR Ejournal, v. 9, p. 11-12, 2007.

Carroll, S.; Goonetilleke, A.; Thomas, E. Integrated risk framework for on-site wastewater treatment systems. Environmental Management Journal, v. 38, p. 286-303, 2006.

Chukwurah, E. I. Aquatic microbiology. Onitsha, Nigeria: Otoba Press, 2001.

Dagnew, T.; Assefa, D.; Aberra, G.; Woldemariam, G.; Solomon, F.; Oliver, S. Rapid assessment of drinking water quality in The Federal Democratic Republic of Ethiopia: Country report of the pilot project implementation in 2004-2005. 2010.

Dissanayake, S. A. M.S.; Dias, S. V.; Perera, M. D. C.; Iddamalgoda, I. A. V. P. Microbial quality assurance of drinking water supplies through surveillance. Proceedings of the Water Professionals Symposium, (WPS'04), Colombo, Sri Lanka, 2004. p. 141-147.

Eiswirth, M.; Hotzl, H. The impact of leakink sewers on urban groundwater. In: Chilton J. (Eds.). Groundwater in the urban environment: Problems, processes and management. Rotterdam, Netherlands: Balkema, 1997. p. 399-404.

Ekiye, E.; Luo, Z. Water quality monitoring in Nigeria; Case study of Nigeria's industrial cities. Journal of American Science, v. 6, p. 1-7, 2010 .

Farzana, K.; Hameed, A.; Waqas, M. K.; Murtaza, G.; Saqib, Q. N. U.; Waseem, A.; Asad, M. H. H. B.; Hussain, I. Bactericidal activity of various brands of cephradine against Staphylococcus aureus. International Journal of Physical Science, v.6, no. 6, p. 1501-1507, 2011.

Fasunwon, O.; Olowofela, J.; Akinyemi, 0.; Fasunwon, B.; Akintokun, O. Contaminants evaluation as water quality indicator in Ago Iwoye, South-Western, Nigeria. African Physical Review, v. 2, p. 287-293, 2008.

Federal Ministry of Water Resources. Final draft on national water sanitation policy. 
Nigeria: Department of Water Supply and Quality Control, 2004.

Guevart, E.; Noeske, J.; Essomba, J. M.; Edjenguele, M.; Bita, A.; Mouangue, A.; Manga, B. Factors contributing to endemic cholera in Douala, Cameroon. Medicine Tropicale, v. 66 , p. 283-291, 2006.

Ibe, S. N.; Okpelenye, J. I. Bacteriological analysis of borehole water in Uli, Nigeria. African Journal of Applied Zoology and Environmental Biology, v. 7, p. 116-119, 2005.

Ifabiyi, I. P. Depth of hand dug wells and water chemistry: Example from Ibadan Northeast Local Government Area (L.G.A.), Oyo-State, Nigeria. Journal of Social Sciences, v. 17, p. 261-266, 2008.

Ince, M.; Bashir, D.; Oni, O. O. O.; Awe, E. O.; Ogbechie, V.; Korve, K.; Adeyinka, M.; Olufolabo, A. A.; Ofordu, F.; Kehinde, M. Rapid assessment of drinking-water quality in the Federal Republic of Nigeria: Country report of the pilot project implementation in 2004-2005. World Health Organization and UNICEF, 2010.

Jamieson, R.; Gordon, R.; Joy, D.; Lee, H. Assessing microbial pollution of rural surface waters: a review of current watershed late modeling approaches. Journal of Agricultural Water Management, v. 70, p. 1-17, 2004.

Kelly, P. B.; Ndubani, K. S.; Nchito, P.; Luo, N. A.; Feldman, R. A.; Farthing, M. J. Cryptosporidiosis in adults in Lusaka, Zambia and its relationship to oocyst contamination of drinking water, Journal of Infectious Disease, v. 176, p. 1120-1125, 1997.

Khalid, A.; Malik, A. H.; Waseem, A.; Zahra, S.; Murtaza, G. Qualitative and quantitative analysis of drinking water samples of different localities in Abbottabad district, Pakistan. International Journal of the Physical Sciences, v. 6, p. 7480-7489, 2011.

Khalid, A.; Rehman, U. U.; Sethi, A.; Khilji, S.; Fatima, U.; Khan, M. I.; Waqas, M. K.; Qazi Najam-us-Saqib, Q.; Asad, M. H. H. B.; Farzana, K.; Mahmood, S.; Waseem, A.; Ismail, T.; Murtaza, G. Antimicrobial activity analysis of extracts of Acacia modesta, Artimisia absinthium, Nigella sativa and Saussure alappa against Gram positive and Gram negative microorganisms. African Journal of Biotechnology, v. 10, p. 4574-4580, 2011.

Khalid, A.; Waseem, A.; Saadullah, M.; Rehman, U. U.; Khiljee, S.; Sethi, A.; Asad, M.;
Rasool, F.; Waqas, M. K.; Murtaza, G. Antibacterial activity analysis of extracts of various plants against gram-positive and gram-negative bacteria. African Journal of Pharmacy and Pharmacology, v. 5, p. 887893, 2011.

Kramer, M.H.; Herwald, T. B. L.; Craun, G. F.; Calderon, R. L.; Juranek, D. D. Surveillance for waterborne disease outbreaks-United States, 1993-1994. MMWR CDC Surveillance Summary, v. 45, no. 1, 1996.

Kumasi, C. T.; Kwasi, O.; Ephraim, J. H. Microbial quality of water in Barekese Reservoir and Feeder Streams in Ghana. Lakes and Reservoirs: Reservoir Management, v. 16, p. 49-60, 2011.

Lewis, W. J.; Foster, S. S. D.; Drasar, B. S. The risk of groundwater pollution by on-site sanitation in developing countries: A literature review. IRCWD/SANDEC Report No. 01/82 1982.

Lin, C. Y.; Abdullah, M. H.; Musta, B.; Aris, A. Z.; Praveena, S. M. Assessment of selected chemical and microbial parameters in groundwater of Pulau Tiga, Sabah, Malaysia. Sains Malaysian, v. 39, no. 3, p. 337-345, 2010.

Longe, E. O.; Balogun, M. R. Groundwater quality assessment near a municipal landfill, Lagos, Nigeria. Research Journal of Applied Science, Engineering and Technology, v. 2, p. 39-44, 2010.

Mackenzie, W. R.; Schell, W. L.; Blair, K. A.; Addiss, D. G. Massive outbreak of waterborne cryptosporidium infection in Milwaukee, Wisconsin: Recurrence of illness and risk of secondary transmission. Clinical Infectious Diseases, v. 1, p. 57-62, 1995.

Moore, A. C.; Herwald, B. L.; Craun, G. F., Calderon, R. L.; Highsmith, A. K.; Juranek, D. D. Surveillance for waterborne disease outbreaks-United States, 1991-1992. MMWR CDC Surveillance Summary, v. 42, p. 110115, 1993.

Morris, B. L.; Lawrence, A. R. L.; Chilton, P. J. C.; Adams, B.; Calow, R. C.; Klinck, B. A. Groundwater and its susceptibility to degradation: A global assessment of the problem and options for management. Nairobi, Kenya: United Nations Environment Programme, 2003. (Early Warning and Assessment Report Series. RS. 03-3).

Muruka, C.; Fagbamigbe, F. A.; Muruka, A.; Njuguna, J. Otieno, D. O.; Onyando, J.; Wanjiku, Z. S.; Onyango, Z.; Wamalwaet, D. 
The relationship between bacteriological quality of dug-wells and, pit latrines siting in an unplanned peri-urban settlement: A case study of Langas-Eldoret Municipality, Western Kenya. Public Health Research, v. 2, p. 32-36, 2012.

Nguendo-Tongsi, H. B. Microbiological evaluation of drinking water in a subSaharan urban community (Yaounde), American Journal of Biochemistry and Molecular Biology, v. 1, p. 68-81, 2011.

Nollet, M. L. L. Handbook on water analysis. New York: Marcel Dekker, 2000.

Nwachukwu, C. I.; Otokunefor, T. V. Bacteriolgical quality of drinking water supplies in the University of Port Harcourt, Nigeria. Nigerian Journal of Microbiology, v. 20, p. 1383-1388, 2006.

Odai, S. N.; Dugbantey, D. D. Towards pollution reduction in Urban water supply: A case study of Ashanti Region in Ghana, Diffuse Pollution Conference, Dublin, v. 14, p. 72-75, 2003.

Ogedengbe, O.; Aina, P. Co-existing Water Wells and Pit-latrines. Nigerian Journal of Science, v. 14, p. 197-205, 1980.

Okafor, N. Aquatic and water microbiology.

Enugu, Nigeria: Fourth Dimension Publishers, 1985.

Okpokwasili, G. C.; Akujobi, T. C. Bacteriological indicators of tropical water quality. Environmental Toxicology and Water Quality, v. 11, p. 77-82, 1996.

Olabisi, 0. E.; Awonusi, A. J.; Adebayo, 0. J. Assessment of bacteria pollution of shallow well water in Abeokuta, Southwestern Nigeria. Life Science Journal, v. 5, p. 59-65, 2008.

Olatunji, J. J.; Oladepo, K. T. Microbiological quality of water collected from unlined wells located near septic-tank-soakaway and pit latrines in Ife North Local Government Area of Osun State, Nigeria. Transnational Journal of Science and Technology, v. 3, p. 10-11, 2013.

Olobaniyi, S. B.; Ogala, J. E.; Nfor, N. B. Hydrogeochemical and bacteriological investigation of groundwater in Agbor Area, Southern Nigeria. Journal of Mining and Geology, v. 43, p. 79-89, 2007.

Oluwande, P. A. Environmental health for rural areas: Principles and practice of community health in Africa. Ibadan, Nigeria: University Press, 1985.
Omenka, E. Improvement of decentralised wastewater treatment in Asaba, Nigeria. Lund, Sweden: Lund University, 2010. (Thesis).

Onunkwo, A.; Uzoije, A. P. Exploratory survey of geochemical aspects of underground water in Ehime Mbano Area, Southeast Nigeria. Global Journal of Research in Engineering, v. 11, p. 14-22, 2011.

Oparaocha, E. T.; Iroegbu, O. C.; Obi, R. K. Assessment of quality of drinking water sources in the Federal University of Technology, Owerri, Imo State, Nigeria. Journal of Applied Biosciences, v. 32, p. 1964-1976, 2008.

Orebiyi, E. O.; Awomeso, J. A.; Idowu, O. A.; Martins, O.; Oguntoke, O.; Taiwo, A. M. Assessment of pollution hazards of shallow well water in Abeokuta and Environs, Southwest, Nigeria. American Journal of Environmental Sciences, v. 6, no. 1, p. 5056, 2010.

Quenum, M. K. WASH Campaign in West Africa: Making water hygiene and sanitation a priority for all. Running Water, v. 6, p. 910, 2003.

Rajendran, P.; Murugan, S.; Raju, S.; Sundararaj, T.; Kanthesh, B. M.; Reddy, E. V. Bacteriological analysis of water samples from Tsunami Hit Coastal Areas of Kanyakumari District, Tamil Nadu. Indian Journal of Medical Microbiology, v. 24, p. 1146, 2006.

Sangodoyin, A.Y. Consideration on Contamination of Groundwater by Waste Disposal Systems in Nigeria. Environmental Technology, v. 14, p. 957-964, 1993.

Shittu, O. B.; Olaitan, J. O.; Amusa, T. S. Physico-chemical and bacteriological analyses of water used for drinking and swimming purposes in Abeokuta, Nigerian. African Journal of Biomedical Research, v. 11, p. 285-290, 2008.

Sridhar, M. K. C. Ground water in Nigerian urban centres: Problems and options. Ibadan, Nigeria: Division of Environmental Health, College of Medicine, University of Ibadan, 2000.

USEPA - United States Environmental Protection Agency. National water quality inventory. Washington, D. C.: USEPA, Office of Water, 1994. (Report to United States Congress). 
USEPA - United States Environmental Protection Agency. National Primary Drinking Water Regulations. Washington, D. C: USEPA, 2009.

USEPA - United States Environmental Protection Agency. Waste disposal practices and their effects on ground water. Washington, D. C.: USEPA, 1977. (Report to United States Congress).

Ushurhe, 0.; Origho, T. Effect of underground on-site sewage disposal system on the quality of water from Hand Dug Wells in the urban centre of Ughelli, Delta State, Nigeria. Standard Journal of Education and Essay, v. 1, p. 81-90, 2013.

WHO - World Health Organisation. Targeting resources for better results. Geneva: World Health Organization, UN - Water Global Annual Assessment of Sanitation and Drinking-Water (GLAAS), 2010.
WHO - World Health Organization. Guidelines for drinking-water quality: Health criteria and other supporting information. 2. ed. Geneva, Switzerland: WHO, 1996. v. 2.

WHO - World Health Organization. Guidelines for drinking-water quality. 3. ed. Geneva, Switzerland: WHO, 2008. v. 1. (Incorporating the First and Second Addenda, Recommendations). 